\title{
Driving Toward Certainty In UCC Financing Statements: Why Alternative A In The 2010 Amendments To UCC § 9-503(a)(4) Is The Best Rule For Listing Individual Debtor Names*
}

Steven Z. Hodaszy, J.D., LL.M., Robert Morris University, USA

\begin{abstract}
In 2010, the sponsors of the Uniform Commercial Code ("UCC") approved certain amendments (the "2010 Amendments") to UCC Article 9, which deals with secured transactions. Chief among the 2010 Amendments was a change to $\$ 9-503(a)(4)$, which concerns how the names of individual debtors are to be listed on UCC financing statements that creditors file to perfect their security interests in a debtor's collateral for a secured loan. Prior to the 2010 Amendments, which became effective in most U.S. States in July 2013, parties to secured transactions were sometimes uncertain as to how a particular individual debtor's name was required to be listed under $\$ 9-503($ a)(4). That uncertainty, in turn, occasionally resulted in a creditor failing to receive a security interest it had bargained for-and thought it had gotten. To remedy those problems, the 2010 Amendments included two alternative amendments to the individual-debtor-name rule under $\$ 9-503($ a)(4)_-Alternative A" and "Alternative B"-and left it to each State to decide which alternative to enact. This Article discusses why Alternative A (which requires an individual debtor's name on a financing statement to match the name on his or her driver's licen se) provides the best way to remove the ambiguities that existed under the priorversion of $\$ 9-503(a)(4)$. The Article further explains how sub-rules within Alternative B essentially repeat the same vague standard for listing individual debtor names that existed under the "old" rule, and why Alternative B therefore perpetuates the very risks to creditors who make secured loans to individuals that the 2010 Amendments were intended to eliminate. The Article argues that, if and when such risks under Alternative B begin to cause harm to secured creditors, lawmakers in States that have adopted Alternative B (as well as the UCC's sponsors themselves) should consider a switch to Alternative A. In the meantime, the Article offers suggestions as to how secured parties can better protect against those risks when filing financing statements, or searching for previously-filed financing statements, against individual debtors in Alternative $B$ jurisdictions.
\end{abstract}

Keywords: Uniform Commercial Code; Article 9; Financing Statements; 2010 Amendments; Alternative A; Alternative B

*Copyright (C) 2016 by Steven Z. Hodaszy. This Article is adapted (with revisions) from a paper of the same name that the author presented at the Clute Institute 2016 International Academic Business Conference in Washington, D.C. This Article supersedes such earlier paper. 


\section{INTRODUCTION: AN OVERVIEW OF UCC ARTICLE 9 AND THE 2010 AMENDMENT TO THE RULE FOR INDIVIDUAL DEBTOR NAMES ON UCC FINANCING STATEMENTS}

The Uniform Commercial Code ("UCC") is a comprehensive model statutory code that covers virtually all aspects of American commercial law. ${ }^{1}$ The UCC was originally drafted, and is from time to time revised or amended, by commercial law experts under the auspices of two national sponsoring organizations - the National Conference of Commissioners on Uniform State Laws ("Uniform Law Commission" or "ULC") and the American Law Institute ("ALI"). The UCC is comprised of 13 "Articles," ten of which contain substantive model legal rules concerning particular types of commercial transactions. ${ }^{2}$ (The other three Articles contain various "general" or procedural provisions. ${ }^{3}$ ) The purpose of the UCC is not only to promote just and practical rules of commercial law, but also to foster uniformity in the country's commercial laws across all U.S. jurisdictions. Because the UCC is a model code, a UCC provision does not become effective in any given jurisdiction unless and until it is enacted as law in that particular jurisdiction. ${ }^{4}$ Accordingly, once the code's sponsoring organizations approve a UCC provision—or a revision thereof or amendment thereto-for inclusion in the code's "Official Text," the ULC actively promotes adoption of that provision, revision or amendment in each U.S. State (as well as in the District of Columbia and various U.S. territories). ${ }^{5}$

Revised Article 9 of the UCC ("Article 9") sets forth laws governing secured transactions. The ULC itself posits that Article 9 "may be the most important of" the UCC's substantive Articles. ${ }^{6}$ It is referred to in the Official Text of the UCC as "Revised Article 9" because, in 1998, the ULC and the ALI approved substantial, comprehensive revisions to the entire Article. With only limited variations from jurisdiction to jurisdiction, Article 9 (as so revised) has been adopted in all 50 States, the District of Columbia, Puerto Rico, and the U.S. Virgin Islands. ${ }^{7}$ (The 1998 revisions became effective in most of those jurisdictions on or about July 1, 2001.) For reasons described below, in 2010 the UCC's sponsors approved certain further amendments (the "2010 Amendments") to the Official Text of (Revised) Article 9.8 The most significant of the 2010 Amendments sets forth two alternative changes to the rule for listing an individual debtor's name on a UCC financing statement. Those changes-and, ultimately, which alternative new rule makes the most sense-are the subjects of this Article.

In general, a secured transaction is a loan or credit transaction, in connection with which the borrower (or "debtor") grants a security interest to the lender or creditor (the "secured party") in certain collateral that the debtor pledges as security for the debt. ${ }^{9}$ If the debtor later defaults on the debt, the security interest gives the secured party the right to take possession of the collateral, ${ }^{10}$ sell the collateral in a commercially reasonable manner, ${ }^{11}$ and apply the proceeds

\footnotetext{
${ }^{1}$ See https://law.duke.edu/lib/researchguides/ucc/ (section I of Duke Law School webpage providing useful, succinct synopsis of “What is the UCC?") (last visited on May 12,2016).

${ }^{2}$ See id. (section II of webpage, entitled "Organization of the UCC," listing those 10 Articles of the UCC and the subject matter of each).

3 See id. (briefly describing Article 1's "general" provisions-which include certain definitions of terms used in other Articles-and the procedural provisions of Article 10 and Article 11).

${ }_{5}^{4}$ See id. (section I of webpage).

${ }_{6}^{5}$ See id.

6 See http://www.uniformlaws.org/ActSummary.aspx?title=UCC\%20Article\%209,\%20Secured\%20Transactions\%20 (1998) (ULC webpage providing summary of Article 9) (last visited on May 12, 2016).

7 See $\mathrm{http} / / / \mathrm{www}$.uniformlaws.org/Act.aspx?title=UCC\%20Article\%209,\%20Secured\%20Transactions\%20(1998) (ULC webpage containing "enactment status map" that indicates U.S. jurisdictions that have enacted Article 9) (last visited on May 12, 2016).

8 All references to the 2010 Amendments or to any section of Article 9 that has been amended thereby are to the Official Text of AMENDMENTS TO Uniform Commercial Code ARTiCle 9, as approved by the ULC and the ALI in 2010. All other references herein to Article 9 of the UCC or to any section thereof are to the Official Text of REVISION OF UNIFORM COMMERCIAL CODE REVISED ARTICLE 9-SECURED TRANSACTIONS, as approved by the ULC and the ALI in 1998. For a detailed synopsis of the 2010 Amendments and an overview of the drafting process that led to their promulgation, see Edwin E. Smith, A Summary of the 2010 Amendments to Article 9 of the Uniform Commercial Code, 42 UCC L.J. 345 (2010); see also David Fri sch, The Recent Amendments to UCC Article 9: Problems and Solutions, 45 U. RICH. L. Rev. 1009 (2011) (describing the development, and outlining the most significant provisions, of the 2010 Amendments).

${ }^{9}$ First and foremost, a secured transaction governed by Article 9 includes "a transaction, regardless of its form, that creates a security interest in personal property or fixtures by contract." UCC § 9-109(a)(1) (2010). However, a "secured transaction" within the scope of Article 9 also includes, inter alia, "a sale of accounts, chattel paper, payment intangibles and/or promissory notes," unless such sale was "part of a sale of the business out of which [such items of property] arose." UCC $\S \S 9-109$ (a)(3), (d)(4) (2010). Thus, the UCC defines a "security interest" not only to include "an interest in personal property or fixtures which secures payment or performance of an obligation[,]" but also to include, inter alia, "any interest of a ... a buyer of accounts, chattel paper, a payment intangible, or a promissory note in a transaction that is subject to Article 9." UCC § 1-201(b)(35) (2001).

${ }^{10}$ See UCC \& 9-609 (2010).
} 
of the sale to the satisfaction of the debt. ${ }^{12}$ Article 9 governs the establishment and enforcement of security interests in "fixtures," 13 tangible personal property other than motor vehicles, ${ }^{14}$ and most intangible personal property. ${ }^{15}$ (Article 9 generally does not cover security interests in real property.) $)^{16}$

In order for a secured party to enjoy the full benefit and protection that a security interest is intended to provide, two things are necessary. First, of course, the secured party must be able to enforce the security interest directly against the debtor. In order for an Article 9 security interest to be enforceable against the debtor who granted it, the security interest need simply to have been created - or, more precis ely, to have "attached" 17 to the pledged collateral.

Often equally important, however, is that the security interest be able to withstand challenges that may be brought by third-parties asserting conflicting interests in the collateral. For example, imagine that a debtor grants a security interest in certain collateral to one secured party, to secure the repayment of a loan made by that secured party, and that the same debtor subsequently grants another security interest in the same collateral to a different secured party, to secure the repayment of another loan. In such a case, if the debtor defaults on the either loan, the first secured party will want to prove that it has the most senior interest in the collateral, so that any sales proceeds will be applied first to satisfy the debtor's obligations to such party. ${ }^{18}$ Accordingly, the first secured party will want to prevent the second secured party from successfully asserting that $i t$ has the senior right to the collateral. Of course, unless the second secured party knowingly and intentionally took a subordinate security interest in the collateral, that party will presumably want just the opposite.

Similarly, imagine that a debtor grants a security interest in certain collateral to a secured party, to secure repayment of a loan, and that the debtor subsequently files for bankruptcy. If the trustee in the bankruptcy proceeding is required to respect the security interest, the secured party will still be able to take and sell the collateral and repay itself with the sales proceeds. When possible, however, the bankruptcy trustee will want to "avoid" (or ignore) a creditor's security interest, in order to spread the debtor's bankruptcy estate more proportionately among all of the debtor's creditors. If the bankruptcy trustee is permitted to avoid the security interest, the "secured" lender will be reduced to sharing the applicable portion of the debtor's bankruptcy estate with all of the debtor's other unsecured creditors - which typically will result in a much smaller recovery, and greater loss, to the lender.

In order for any security interest governed by Article 9 to be able to withstand such a third-party challenge (from another secured creditor or from a trustee in bankruptcy), the security interest must not only have attached; it must also have been "perfected." 19 The basic aim of this "perfection" requirement is to provide prospective creditors (and some prospective purchasers ${ }^{20}$ ) with notice of existing security interests in property that the prospective creditor may be contemplating to accept as collateral for a loan (or that the prospective purchaser may be considering to purchase). ${ }^{21}$ The most common method of "perfecting" a security interest in most categories of Article 9 collateral is

\footnotetext{
${ }^{11}$ See UCC § 9-610 (2010). For the standards by which to determine whether such a sale is "commercially reasonable," see UCC § 9-627.

12 See UCC $\$$ 9-608, 9-615 (2010).

13 Under Article 9, "[f]ixtures' means goods that have become so related to particular real property that an interest in them arises under real property law." UCC § 9-102(a)(41) (2010).

${ }^{14}$ Article 9 does not apply when "another statute of [the applicable] State expressly governs the creation, perfection, priority, or enforcement of a security interest." UCC §9-109(c)(2) (2010). Because security interests in motor vehicles are governed by State titling statutes, such security interests are outside the ambit of Article 9.

${ }^{15}$ For a list of certain intangible property rights, security interests in which are not governed by Article 9, see UCC §§ 9-109(d)(1)-(10), (12)-(13) (2010).

${ }^{16}$ See UCC $\$ 9-109(d)(11)(2010)$.

17 "The creation of a security interest under Article 9 is embodied in the concept of 'attachment." Frisch, supra note 8, at 1012. Under $\S 9-203$ (a), a security interest attaches to collateral when it becomes enforceable against the debtor. See UCC § 9-203(a) (2010). Section 9-203(b) sets forth the prerequisites to enforceability of a security interest, which are that (i) value has been given, (ii) the debtor has rights in the collateral and power to transfer those rights to a secured party, and (iii) the debtor has either authenticated a security agreement describing the collateral or (in some cases, depending on the collateral) has delivered possession or control of the collateral to the secured party. See UCC § 9-203(b) (2010).

${ }^{18}$ Article 9 provides that any cash proceeds of a sale of collateral will be applied to the satisfaction of the debtor's secured obligation s to a subordinate secured party only if, and to the extent that, any such proceeds remain after the debtor's secured obligations to the senior secured party have been satisfied in full. See UCC $\$ \S 9-608(a)(1)(B), 9-608(a)(1)(C), 9-615(a)(1), 9-615(a)(3)(A)(2010)$. See also infra notes 53 \& 65 (discussing Article 9's priority rules and the consequences thereof).

${ }^{19}$ For additional discussion of the "perfection" of a security interest, as that term of art is used in Article 9, see infra note 45.

${ }^{20}$ See infra note 53 (discussing the effectiveness of Article 9 security interests vis-à-vis various categories of subsequent purchasers of collateral).

${ }^{21}$ For more on the purpose of Article 9's perfection requirement, see infra text accompanying notes 64-67.
} 
to file (in the designated filing office ${ }^{22}$ of the appropriate jurisdiction) a concise document known as a "UCC financing statement." 23 Once filed, a UCC financing statement is a publicly-available document. Thus, after a secured party files a financing statement against the debtor who granted the security interest in the collateral listed on the statement, subsequent interested parties - e.g., pros pective secured creditors who might lend against the s ame collateral and certain "non-ordinary-course" buyers who might buy the collateral24_can search for the financing statement (in the database of the appropriate filing office) to find out whether the collateral is encumbered by the security interest.

Although a UCC financing statement is an intentionally short, simple document, one item it obviously needs to contain is the name of the debtor against whom it is filed. Section 9-503 of the UCC provides rules as to how a debtor's name is required to be listed on a financing statement. If the name is not listed in accordance with the applicable rule, the financing statement will not be "effective"-i.e., filing it will not perfect the related security interest. Different rules apply to different categories of debtors (e.g., individual persons, registered organizations, ${ }^{25}$ and trusts that are not registered organizations). However, in the case of a debtor who is an individual person (as opposed to, say, a business entity) the pre-2010-amendment version of $\S 9-503(a)(4)(A)$ (the "Old Rule") simply required a financing statement to list the "individual name of the debtor," 26 without going into any further detail as to what constitutes the individual's name or how that name should be listed.

The lack of specificity in the Old Rule for individual debtor names caused confusion in a number of cases. As discussed further below, ${ }^{27}$ it turns out that a surprising number of individuals can be said to have more than one name (or, at least, more than one version of their name). A number of other individuals have names that follow non Anglo conventions (e.g., with regard to which part of the name constitutes the person's surname) that may be unfamiliar to some. In cases where an individual in one of those categories was a debtor in a secured transaction, there often was uncertainty as to how the secured party should list the debtor's name when preparing and filing a related financing statement. There also was similar uncertainty as to which name (or names) to search under, when an interested party wanted to search for financing statements that may have been filed against such a debtor.

This uncertainty manifested itself in several controversial court decisions during the decade following the adoption of Revised Article 9. ${ }^{28}$ In each such case, a secured creditor was left without the security interest it thought it had, as a result of the reviewing court's decision regarding the sufficiency (or insufficiency) of the way an individual debtor's name was listed on a financing statement. In a number of those cases, a secured party was left with an unperfected security interest in its collateral because the debtor's name on the financing statement was found to have been insufficient, even though the secured party believed in good faith that it had listed the debtor's correct name. Conversely, in perhaps the most surprising of the cases, a court found that a remarkably informal variation of a debtor's name was sufficient for a financing statement filed by a secured party. ${ }^{29}$ As a result, another secured creditor of the same debtor-which did not foresee the need to conduct a filing search under a name so divergent from the debtor's formal name-was left with no more than a second-priority interest in its collateral, rather than the first-priority interest it had expected.

\footnotetext{
${ }^{22}$ Section 9-501 sets forth the rules for determining the appropriate filing office for any particular financing stat ement. With limited exceptions-e.g., in the case of fixture filings or filings where the debtor is a transmitting utility - the correct filing office will be usually be the State-level filing office of the State whose laws govern the perfection of the security interest. See UCC § 9-501 (2010); see also infra note 57 and accompanying text (discussing § 9501 's rules establishing appropriate filing offices for various financing-statement filings).

${ }^{23}$ See infra text accompanying notes 54-63 (discussing prevalence of perfection by filing, compared to perfection by other methods).

${ }^{24}$ See infra note 53 (discussing the effectiveness of a perfected security interest against a subsequent purchaser who buys the collateral outside the ordinary course of business).

${ }^{25}$ Under Article 9, a "registered organization" is defined as "an organization organized solely under the law of a single State or the United States by the filing of a public organic record with, the issuance of a public organic record by, or the enactment of legislation by the St ate or the United States. The term includes a business trust that is formed or organized under the law of a single State if a statute of the State governing business trusts requires that the business trust's organic record be filed with the State." UCC § 9-102(a)(71) (2010).

${ }^{26}$ For the exact wording of the Old Rule under pre-amendment $\$ 9-503(\mathrm{a})(4)(\mathrm{A})$ in entire relevant part, see infra text accompanying note 78.

${ }^{27}$ See infra text accompanying notes 80-82.

${ }^{28}$ For a detailed discussion of those cases, see infra Part III.

${ }^{29}$ See Bryan Bros. Cattle Co., 504 F.3d 549. For a description of the case, see infra text accompanying notes 102-18.
} 
As reflected in those cases, the uncertainty under the Old Rule as to how to list certain individual debtors' names led some filers to file ineffective financing statements and prevented searchers from discovering some financing statements that were effective. Due to both types of errors, some (supposedly) secured parties ended up without the benefit of a security interest they had bargained for, and they sometimes incurred significant losses as a result.

Prompted by the secured lending community's concern and some ill-conceived responses by a few individual States ${ }^{30}$ the UCC's sponsoring organizations eventually recognized the need to address the ambiguity in the Old Rule for individual debtor names. In 2008, the ULC and the ALI appointed a Joint Review Committee (the "Review Committee") to analyze the problem and propose a legislative solution. ${ }^{31}$ The Review Committee's work culminated in the 2010 Amendments. While the 2010 Amendments modify a number of Article 9 provisions, the most significant emendation is the change is to the rules under § 9-503(a)(4) for determining whether a UCC financing statement sufficiently lists an individual debtor's name. The intent of the 2010 amendment to UCC § 9-503(a)(4) was to provide clearer, more precise rules about just how to set forth an individual debtor's name on a financing statement. However, various members of the Review Committee favored different instructions for listing individual debtors' names. ${ }^{32}$ For that reason, the final version of amended $\S 9-503(a)(4)$ actually consists of two alternative rules, from which each enacting jurisdiction could choose. ${ }^{33}$

The first alternative, known as "Alternative A," essentially provides that the only permissible way to list an individual debtor's name on a financing statement is to use the version of the debtor's name that matches exactly character for character - the name that is listed on his or her most recent unexpired driver's license (or on his or her State-issued non-driver identification card, if the debtor does not have a driver's license). ${ }^{34}$ The second alternative, known as "Alternative B," provides that the listing of an individual debtor's name on a financing statement is automatically sufficient if it matches the name on the debtor's driver's license (or, if applicable, the debtor's nondriver identification card). ${ }^{35}$ However, in a misguided attempt to provide greater "flexibility," Alternative B also permits other listings, as long as they "provide[] the surname and first personal name of the debtor" 36 or otherwise "provide[] the individual name of the debtor." 37 Unfortunately, the non-driver's-license alternatives under Alternative B essentially replicate the same vague "nonstandard" for individual debtor names that had been in effect under the pre-amendment version of $\S 9-503(a)(4)(A)$.

During the several years that followed their approval by the UCC's sponsors, the 2010 Amendments were by considered by State legislatures throughout the country - and, in many cases, deliberated within State bar associations that made recommendations to those legislatures as to the form in which to adopt the amendments. This author, for example, first studied the 2010 Amendments while serving as a member of the Uniform Commercial Code Task Force of the Business Law Section of the Pennsylvania Bar Association (the "PA Task Force"). The PA Task Force drafted the bill setting forth Pennsylvania's version of the 2010 Amendments and prepared a report to the Pennsylvania legislature recommending the enactment of the amendments (the "PA Task Force Report"). ${ }^{38}$ Other States' versions of the 2010 Amendments were developed in similar ways. Ultimately, the

\footnotetext{
${ }^{30}$ See infra text accompanying notes $137-38$ (discussing certain poorly developed non-uniform amendments to $§ 9-503$ (a)(4) that several States enacted in response to secured lenders' concerns about lack of clarity under the Old Rule).

${ }^{31}$ See Smith, supra note 8, at 348; Frisch, supra note 8, at 1010.

32 See infra text accompanying notes 147-52 (discussing differing views of Review Committee members).

${ }^{33}$ See UCC $\$ 9-503(\mathrm{a})(4)$ (Alts. A and B) (2010) (as amended by 2010 Amendments).

${ }^{34}$ UCC $\S 9-503(a)(4)$ (Alt. A) (2010) (as amended by 2010 Amendments). The precise wording of Alternative A is reproduced infra in the text accompanying notes $155-58$.

${ }^{35}$ UCC \$ 9-503(a)(4)(C) (Alt. B) (2010) (as amended by 2010 Amendments).

${ }^{36}$ UCC $\$ 9-503($ a)(4)(B) (Alt. B) (2010) (as amended by 2010 Amendments).

${ }^{37}$ UCC $\$ 9-503(a)(4)(A)$ (Alt. B) (2010) (as amended by 2010 Amendments). The precise wording of Alternative B is set forth infra, at text accompanying note 160 .

38 See Report on the Amendments to Article 9 of the Uniform Commercial Code, Secured Transactions-Recommended for Adoption by the Uniform Law Commission on July 16, 2010, 83 PA BAR ASs'N QUARTERLY 101 (2012) [hereinafter, the PA Task Force Report]. This Article expands upon, and updates, arguments in favor of Alternative A under UCC § 9-503(a)(4), which the author originally advanced within the PA Task Force during preparation of the PA Task Force Report. However, the views expressed in this Article, and any errors or omissions herein, are solely those of the author.
} 
2010 Amendments were enacted in all 50 U.S. States, the District of Columbia and Puerto Rico. ${ }^{39}$ In most jurisdictions, the 2010 Amendments became effective on July 1, 2013. ${ }^{40}$

All but seven of the jurisdictions that enacted the 2010 Amendments eventually chose Alternative A. The States that, as of now, operate under Alternative B are Alaska, Colorado, Connecticut, Delaware, New Hampshire, Oregon and Wyoming. ${ }^{41}$ This Article explains why the majority of jurisdictions, which adopted Alternative A, got the issue right and why the minority that went with Alternative B got it wrong. Alternative A provides a far better rule than Alternative B for determining whether a financing statement sufficiently lists an individual debtor's name. The uncertainty under the Old Rule — and the resulting risks to both filers and searchers of financing statements — can be eliminated only by adopting a single, uniform convention for listing individual debtors' names, and requiring all filers always to follow that convention. Alternative A's "only if" rule mandates conformity to just such a convention. Alternative B's “safe harbor” approach does not.

Although both alternatives incorporate a version of the "driver's license rule" for individual debtor names, only Alternative A makes adherence to that clear, simple rule mandatory. In contrast, Alternative B makes the driver's license rule only one of several alternative rules that financing-statement filers may follow. As discussed further below, Alternative B's other permissible rules are every bit as vague as the Old Rule. As a result, only Alternative A provides both filers and searchers of financing statements with the unambiguous guidance on the issue of individual debtor names that the 2010 Amendments were intended to achieve. In short, Alternative A provides the best protection against consequential mishaps in preparing or searching for financing statements filed against individual debtors, because only Alternative A is "fool proof."

In one obvious sense, the debate between Alternative A and Alternative B would seem to be "over with." After all, the 2010 Amendments have now become effective in virtually all Article 9 jurisdictions, ${ }^{42}$ and each of those jurisdictions has chosen which of the two alternatives to adopt. However, the 2010 Amendments have been effective for only about three years. Not enough time has yet passed to allow for a thorough evaluation of filers' and searchers' experiences in Alternative A and Alternative B jurisdictions, respectively. The question of how best to legislate the listing of individual debtor names on a financing statement should not be deemed to be settled until we have more information about how well Alternative A and Alternative B actually work in practice.

For the reasons discussed below, this Article contends that, as between Alternatives A and B, only Alternative A can actually remove the uncertainty, and resulting risks to secured-transaction parties, that existed under the Old Rule. In contrast, Alternative B perpetuates that same uncertainty, and thus those same risks, because it essentially incorporates (within two of its alternative sub-rules) the same nebulous standard for individual debtor names as the Old Rule. As a result, secured parties (or parties that thought they were secured) in Alternative B juris dictions are at

\footnotetext{
39 Among jurisdictions that have enacted Article 9, only the U.S. Virgin Islands has yet to pass the 2010 Amendments. See http://www.uniformlaws.org/ Act.aspx?title=UCC\%20Article $\% 209 \% 20$ Amendments\%20(2010) (ULC webpage containing "enactment status map" that indicates jurisdictions that have enacted the 2010 Amendments) (last visited on May 12, 2016).

${ }^{40}$ In the Official Text of the 2010 Amendments, the ULC and ALI recommended that amendments become effective in all jurisdiction s on July 1, 2013. According to the ULC, the purpose of the uniform July 1, 2013 effective date was to "allow [S]tates to adopt the amendments uniformly and have them become operative simultaneously (thereby avoiding unnecessary conflicts and confusion with respect to interstate transactions)." See http://www.uniformlaws.org/ActSummary.aspx?title=UCC\%20Article\%209\%20Amendments\%20(2010) (last visited on May 12, 2016). In the vast majority of the adopting jurisdictions, July 1, 2013 was in fact the effective date of the 2010 Amendments, although eight ju risdictions opted for effective dates that were either slightly earlier or (in most cases) later. In Puerto Rico, the 2010 Amendments became effective on January 17, 2013. In Missouri, they became effective on August 28, 2013. The effective date in Arizona was April 22, 2014. July 1, 2014 was the effective date in Alaska, California and Vermont. The effective date in New York State was December 17, 2014, and the effective date in Oklahoma was November 1, 2015. In all other jurisdictions that adopted the 2010 Amendments, the amendments became effective on July 1, 2013. See http://csctransactionwatch.com/wpcontent/uploads/2013/06/State-Legislative-Status-Summary-Chart-06052015.pdf (Corporation Service Company webpage listing the respective effective date of the 2010 Amendments in each jurisdiction) (last visited on May 12, 2016).

${ }^{41}$ As of now, Alternative A is in effect in each of the other 43 States, the District of Columbia, and Puerto Rico. See http://csctransactionwatch.com/ wpcontent/uploads/2013/06/2010_Amendments_State_Variations_06292015.pdf (Corporation Service Company webpage providing synopses of differences among various jurisdictions' versions of 2010 Amendments) (last visited on May 12, 2016). Interestingly, the State of Washington initially adopted Alternative B in 2011, but then in 2013 (prior to the effective date of the amendments) switched to Alternative A. See id. Illinois chose to adopt Alternati ve B for financing statements filed through December 31, 2015, but has adopted Alternative A for financing statements filed on or after January 1, 2016. See id. The U.S. Virgin Islands has not yet adopted the 2010 Amendments at all. See id.

${ }^{42}$ Perhaps, if nothing else, this Article can help to sway the U.S. Virgin Islands to enact the 2010 Amendments and to choose Alternative A.
} 
comparatively greater peril of suffering the same sorts of harms that they had experienced under the Old Rule. If those risks come to pass, then the UCC's sponsors and lawmakers in each Alternative B jurisdiction will need to be willing and ready to respond accordingly. In the meantime, secured-transaction parties need to be mindful of the continuing traps for the unwary that exist when filing against, or searching for filings against, individual debtors in Alternative B jurisdictions. ${ }^{43}$

In order to frame the issue, Part II of this Article outlines the rules for perfection of security interests by filing financing statements under Article 9, and discusses the centrality of debtors' names to the system for recording financing statements. Next, Part III of the Article describes the Old Rule's uncertain standard for listing individual debtor names and discusses case law that developed during the decade prior to the adoption of the 2010 Amendments, in which the uncertainty under the Old Rule resulted in creditors' inability to realize on security interests that they thought they had perfected. Part IV outlines how the UCC's sponsors responded to the uncertainty - and corresponding risks - under the Old Rule by adopting the 2010 Amendments, and describes in particular Alternatives A and B of $\S 9-503(\mathrm{a})(4)$, as amended. Then, Part V of the Article discusses Alternative A in detail and explains how and why Alternative A protects both filers and searchers by instituting the "only if" version of the driver's license rule. Thereafter, in Part VI, the Article explains the primary deficiencies of Alternative B, and notes the problems that may be expected to occur in Alternative B jurisdictions as a result. In conclusion, Part VII of the Article offers two primary "takeaways": First, the UCC's sponsors and lawmakers in each Alternative B jurisdiction need to stand ready to make appropriate legis lative adjustments to $\S 9-503(a)(4)$ if and when Alternative B begins to cause the problems that this Article foresees. Second, until then, filers and searchers should be especially mindful of the continuing risks regarding individual-debtor-name listings on financing statements whenever operating in an Alternative B jurisdiction.

\section{THE ROLE OF FINANCING STATEMENTS IN ARTICLE 9'S PERFECTION SYSTEM AND THE CENTRALITY OF DEBTORS' NAMES TO THE CATALOGUING OF FINANCING STATEMENTS}

To some, deciding on the right requirements for how to list an individual debtor's name on a financing statement might seem to be a mind-numbingly tedious exercise. But it is also acutely important to the operation of the secured credit market. Before considering the case for Alternative A in further detail, it is useful to reflect briefly on the significance of having the correct debtor's name on a UCC filing.

As noted above, when a creditor takes a security interest in collateral for a secured loan, the creditor wants to ensure not only that it can enforce its security interest against the debtor, but also that the security interest will withstand potential challenges brought by third-parties who may also claim some interest in the collateral. In order to do so, the creditor must make sure both that the security interest has attached ${ }^{44}$ and that it has been perfected ${ }^{45}$ under the $^{-}$ UCC. $^{46}$ First and foremost, perfection of a security interest is essential to the secured creditor's protection if the debtor becomes the subject of a bankruptcy proceeding. Section 544(a)(1) of the Bankruptcy Code ${ }^{47}$ provides that a debtor's trustee in bankruptcy can "avoid a security interest in personal property that is unperfected on the date of the bankruptcy petition." 48 Thus, an unperfected security interest is essentially "unenforceable in bankruptcy." 49

\footnotetext{
43 Those traps are discussed infra in Part VI.

44 For a discussion of Article 9's concept of "attachment," see supra note 17.

45 "Perfection in Article 9 is a complex term of art. Sections 9-308 through 9-316 specify how one perfects in each of the various transactions under Article 9." James J. White \& Robert S. Summers, UNiform COMMERCIAL CODE (6th ed. 2010), Vol. 4 at 149. Article 9 governs the perfection of security interests in most items of personalty; however, it does not govern the perfection of security interests in all types of collateral. It does not apply to perfection of security interests in real property (except to the limited extent provided under $\S 9-109(\mathrm{~d})(11)$ ), security interests in motor vehicles that are governed by certificate-of-title statutes, and security interests arising from various other categories of transactions specified in $\S 9-109$. See supra text accompanying notes 13-16 (discussing scope of Article 9); see also White \& Summers, supra, at 151 (discussing security interests, the perfection of which is not covered by Article 9).

${ }^{46}$ See James Brook, SECUREd Transactions: EXAMPLES AND EXPLANATIONS 85-86 (4th ed. 2008) (to protect secured creditor's interest to greatest extent possible, security interest must be perfected, not merely attached); White \& Summers, supra note 45, at 149-50 (same); Frisch, supra note 8, at 1012-14 (same).

47 11 U.S.C. $\$ 544(a)(1))(2006)$.

${ }^{48}$ Clark v. Deere \& Co. (In re Kinderknecht), 300 B.R. 47, 48 (Bankr. D. Kan. 2003), rev'd, 308 B.R. 71 (B.A.P. $10^{\text {th }}$ Cir. 2004$)$ (citing 11 U.S.C. $\S$

544(a)(1)), quoted in PA Task Force Report, supra note 38, at 108 n.23.
} 
This alone could render an unperfected security interest almost valueless as a practical matter, given that the need to enforce a security interest arises most often in the context of the debtor's bankruptcy. ${ }^{50}$ Moreover, even outside the bankruptcy context, an unperfected security interest is subordinate to the interest of either a lien creditor ${ }^{51}$ or another secured creditor with a perfected security interest in the same property. ${ }^{52}$ Conversely, a "senior perfected secured creditor prevails against most of its competitors - unsecured creditors, lien creditors, non-ordinary-course buyers, unperfected secured parties, and later perfected secured parties."53

Depending on the kind of collateral and transaction in question, there are four ways in which security interests may be perfected under Article 9.54 However, "by far the most common and important method, is the filing of a financing statement."55 Section 9-310(a) identifies filing as the standard procedure for perfecting a security interest, which secured parties must follow unless Article 9 otherwise permits an alternative or imposes some exception in the case of a particular class of collateral or transaction. ${ }^{56}$ Financing statements are generally required to be filed in the State filing office designated by the State whose law governs perfection of the security interest. ${ }^{57}$

${ }^{49}$ Frisch, supra note 8, at 1013. “[U]nder Bankruptcy Code $\S 544(\mathrm{a})$, , the bankruptcy trustee "is given the rights and powers of a hypothetical creditor who obtains a judicial lien at the date of the bankruptcy, and the trustee may avoid any transfer of property of the debtor that is avoidable by such a judicial lien creditor." Id.

${ }_{50}^{50} I$. ("most ofthe litigation concerning security interests occurs in the bankruptcy context").

${ }^{51}$ UCC § 9-317(a)(2)(A) (2010). " “A lien creditor” is a creditor with a judicial lien" on property to which a competing security interest has attached. Frisch, supra note 8, at 1013 n.20 (citing UCC $§ 9-102(a)(52)$ ).

${ }_{52}$ UCC $\$ 9-322(a)(2)(2010)$ (“A perfected security interest ... has priority over a conflicting unperfected security interest.").

${ }^{53}$ Margit Livingston, A Rose by Any Other Name Would Smell As Sweet (or Would It?): Filing and Searching in Article 9's Public Records, 2007 B Y U L. REV. 111, 145 (2007) (citing applicable UCC sections). The priority rules under Article 9 governing the effectiveness of a creditor's security interest vis-àvis other creditors are as follows: Under $\S 9-201(\mathrm{a})$, any security interest that has attached to collateral (even if unperfected) is effective against a competing claim of right to such property brought by an unsecured creditor. See UCC § 9-201(a) (2010). As noted above, § 9-322(a)(2) grants priority to a perfected security interest over any unperfected interest in the same collateral, and § 9-317(a)(2)(A) places a judgment lien creditor's interest in property ahead of an unperfected security interest therein. In a case where there is more than one perfected security interest in the same item of collateral, § 9322(a)(1) provides that "conflicting perfected security interests . . rank according to priority in time of filing or perfection." UCC § 9-322(a)(1) (2010). The rules regarding the effectiveness of a security interest vis-à-vis a subsequent purchaser of collateral are a bit more complex: Under the general rule of $\S$ 9-201(a), a purchaser of property takes such property subject to any Article 9 security interest that has attached thereto, even if such security interest is unperfected. See UCC \& 9-201(a) (2010) ("Except as otherwise provided in [the UCC], a security agreement is effective according to its terms between the parties, against purchasers of the collateral, and against creditors.") (emphasis supplied). However, by operation of $\S 9-317$ (b), a buyer of goods, tangible chattel paper, tangible documents, instruments or certificated securities outside the ordinary course of business (as defined in § 1-201(b)(9)) takes such property free and clear of any security interest therein, if such buyer takes delivery of such property "without knowledge of the security interest and before it is perfected." UCC § 9-317(b) (2010) (as amended by 2010 Amendments) (emphasis supplied). In other words, non-ordinary-course buyers generally take such property subject to perfected security interests therein, but not subject to unperfected security interests (unless the buyer had actual knowledge of the unperfected interest). Similarly, in the case of consumer goods purchased for personal, family or household purposes, the purchaser takes such goods free and clear of any security interest therein if the purchaser makes such purchase without knowledge of the security interest and before the filing of any financing statement covering such goods (unless the security interest was perfected by possession). UCC $\$$ 9-320(b), (e) (2010). In the case of a buyer of goods in the ordinary course of business (as defined in $\S 1-201(b)(9)$ ), $\S 9-320$ provides that the buyer acquires the purchased goods free of even a prior perfected security interest therein - unless (i) the secured party perfected its security interest in those goods through possession or (ii) the goods in question are "farm products" purchased from "a person engaged in farming operations." UCC §§ 9-320(a), (e) (2010). Section 1-201(b)(9) defines a "buyer in the ordinary course of business," in relevant part, as follows:

"Buyer in ordinary course of business" means a person that buys goods in good faith, without knowledge that the sale violates the rights of another person in the goods, and in the ordinary course from a person, other than a pawnbroker, in the business of selling goods of that kind. A person buys goods in the ordinary course if the sale to the person comports with the usual or customary practices in the kind of business in which the seller is engaged or with the seller's own usual or customary practices. ...

UCC \& 1-201(b)(9) (2001). See also infra note 65 (further discussing Article 9's priority rules and the consequences thereof, and the concomitant importance to a prospective secured creditor or non-ordinary-course buyer of determining whether an item of collateral to be accepted or property to be purchased is encumbered by a prior security interest).

${ }_{54}^{54}$ White \& Summers, supra note 45, at 150 (discussing perfection by filing, possession, or control, and automatic perfection in certain cases). ${ }^{55} \mathrm{Id}$.

${ }^{56} \mathrm{Id}$. at 184 . Section 9-310(a) provides that a financing statement must be filed to prefect a security interest, unless one of the exceptions or alternatives listed under § 9-310(b) (and the other applicable UCC sections cross-referenced therein) applies. UCC §§ 9-310(a), (b) (2010).

${ }^{57}$ UCC § 9-501(a)(2) (2010). A Legislative Note to § 9-501 instructs that the filing office designated by a State "may be that of a governmental official (e.g., the Secretary of State) or a private party that maintains the State's filing system." UCC § 9-501, Legislative Note. There are a few limited exceptions to the general State-level filing rule. In the case of fixture filings or financing statements covering as-extracted collateral or timber to be cut, the appropriate filing office is the office designated for filing or recoding of a mortgage on the related real property. UCC § 9-501(a)(1) (2010). There is also a separate filing-office rule for transmitting utilities. See UCC §9-501(b) (2010). 
Security interests in some types of collateral, including general intangibles and accounts (other than deposit accounts), can be perfected only by filing a financing statement. ${ }^{58}$ Filing is a permitted (though not exclusive) means of perfection as to almost all other classes of Article 9 collateral, including goods, chattel paper, documents, investment property and instruments. ${ }^{59}$ Especially when dealing with goods - and often when dealing with other categories, such as chattel paper or documents - filing a financing statement is indeed "the preferred method of perfection,"60 even if an alternative method exists. Thus, the vast majority (perhaps up to 90\%) of security interests are perfected through filing. ${ }^{61}$ In fact, the only three types of Article 9 collateral in which security interests cannot be perfected through filing are deposit accounts, letter-of-credit-rights, and money. ${ }^{62}$ As Professor David Frisch puts it, "[i]t is fair to say, therefore, that financing statements and the [S]tate filing systems in which they are filed are of paramount importance to the efficient operation of Article 9." 63

The purpose of the perfection requirement - and of perfection by filing, in particular-is to provide notice of any security interest that may be attached to a given item of property, to any prospective creditor or transferee who contemplates acquiring a subsequent interest in such property. ${ }^{64}$ If such a security interest is discoverable beforehand, the would-be creditor or purchaser can make an informed decision whether to proceed with the transaction. ${ }^{65}$ Thus, the goal is to enable a potential buyer, or a potential lender who considers taking a security interest in collateral, to ascertain (through reasonable, but not undue, effort) whether the seller or borrower has granted another party a security interest in the property in question. ${ }^{66}$ In the case of security interests perfected through filing, a search of publically-filed financing statements in the appropriate jurisdiction(s) is supposed to yield that information. ${ }^{67}$

\footnotetext{
58 White \& Summers, supra note 45, at 184; Frisch, supra note 8, at 1014. There is no exception to the general filing requirement under $\S 9$-310(a) for either such category of collateral.

${ }^{59}$ White \& Summers, supra note 45, at 184 . Section 9-312(a) provides that "[a] security interest in chattel paper, negotiable documents, instruments, or investment property may be perfected by filing." UCC § 9-312(a) (2010). And, as noted above, filing is the primary method of perfection with respect to goods, pursuant to $\S 9-310$ (a). However, a security interest in goods, instruments, or tangible chattel paper may also be perfected by taking possession of the collateral (as may be a security interest in money). See UCC $\$ \$ 9-313(a), 9-310(b)(6)(2010)$. In addition, a security interest in investment property, electronic chattel paper or electronic documents (as well as deposit accounts or letter-of-credit rights) may be perfected by control of the collateral. See UCC § 9-314(a) (2010) (cross-referencing other applicable UCC sections); UCC § 9-310(b)(8) (2010).

${ }^{60}$ Frisch, supra note 8, at 1014. "Perfection by taking possession of the goods is also an option, but, in most cases, a far less practical one." Id. at 1014 n.29. Perfection through possession of tangible chattel paper or tangible documents (or through control of electronic chattel paper or electronic documents) is often similarly impractical if the debtor requires continued access to the chattel paper or documents in order to conduct business.

${ }^{61}$ White \& Summers, supra note 45 , at 185 ("We suspect that for more than $90 \%$ of the universe, perfection occurs by some form of filing of a document which the UCC calls a "financing statement."').

${ }^{62}$ UCC $\$ \S 9-312(b)(1)$, (2), (3) (2010); see also White \& Summers, supra note 45, at 184-85 (discussing same).

${ }^{63}$ Frisch, supra note 8 , at 1014.

${ }^{64}$ See id.; see also Livingston, supra note 53, at 117 (The UCC financing statement "was designed . . to signal that certain assets of a particular debtor might be encumbered in favor of a particular creditor.").

${ }^{65}$ Frisch, supra note 8, at 1014-15; Livingston, supra note 53, at 117 . Knowing whether property is encumbered by a pre-existing security interest is critical to deciding whether to accept the property as collateral or whether to purchase it, because the prior security interest affects the extent of the interest in the property that may be subsequently acquired. Under $\$ 9-322(a)(1)$, a subsequent perfected security interest is subordinate to a prior perfected security interest. Thus, the earlier secured party has a right to be repaid from proceeds of the collateral before the later secured creditor (and, absent a contrary intercreditor arrangement between the parties, the subsequent secured creditor has a right only to whatever proceeds may remain after the prior secured creditor has been paid in full). See also supra note 18 (discussing prior rights of senior secured creditor to be satisfied from proceeds of collateral sale before any remaining proceeds are applied to satisfaction of subordinate secured creditor). Except in the case of a buyer in the ordinary course of business, see $\S 9-320$ (a) (2010), or a buyer of consumer goods without knowledge of an existing security interest, see § 9-320(b)(1) (2010), a buyer of goods, tangible chattel paper, tangible documents, instruments or a security certificate generally takes the property subject to any perfected security interest therein. UCC § 9-317(b) (2010) (as amended by 2010 Amendments), UCC § 9-317(e) (2010). See also supra note 53 (discussing Article 9's priority rules and the effectiveness of Article 9 security interests vis-à-vis various categories of subsequent purchasers). Where the general rule of $\S 9-317$ (b) applies, the secured creditor retains its rights under Article 9 to foreclose on the collateral and pay itself from the proceeds, even after the debtor has sold the collateral to a third-party who is under no obligation for the related debt. Although the ordinary-course-of business exception generally excludes property purchased from sellers in the business of selling such property, there are nevertheless many other types of sale transactions (and items of property transferred in such sales) that come within the purview of the general rule.

66 The UCC's drafters "wished to increase the certainty that a good faith effort by the secured creditor at filing would success fully communicate all necessary information, and that a good faith search by later parties would reveal the presence of the earlier secured creditor's claim." White \& Summers, supra note 45 , at 150 .

${ }^{67} I d$. Of course, discovering that collateral is in a secured party's possession will also disclose the existence of a security interest. In the few instances where a security interest is perfected automatically upon attachment, the underlying policy of providing particular protection to certain categories of secured lenders (by ensuring that their security interests can never be unperfected) outweighs the general goal of providing notice to third-parties. In such cases, a prospective creditor or purchaser must rely solely on the debtor or transferee to disclose a prior security interest. Frisch, supra note 8 , at $1015 \mathrm{n} .31$. Section 9-309 lists the categories of security interests that are automatically perfected. See UCC § 9-309 (2010). "The most important of this ... group of
} perfected interests are purchase money interests in consumer goods.” White \& Summers, supra note 45, at 150. See UCC § 9-309(1) (2010). 
Despite (or, perhaps, because of) the important role it plays, a financing statement is designed under Part 5 of Article 9 to be a simple, streamlined document. It is not meant to convey the entirety of the parties' security agreement; rather, it is intended to contain only the minimal information necessary to provide third-parties with notice that a given item of property may be encumbered by a security interest. ${ }^{68}$ (After finding the financing statement, a searcher is expected to conduct further inquiry to determine the details of the security arrangement. ${ }^{69}$ ) Under this "notice filing" approach, a financing statement generally is sufficient if it simply provides (1) the name of the debtor, (2) the name of the secured party, and (3) an indication of the collateral covered by the financing statement. ${ }^{70}$

Of these, by far the most critical item of information is the debtor's name. Filing officers are required to index financing statements according to the name of the debtor. ${ }^{71}$ Therefore, "searching parties inevitably search for financing statements under the name of the person with whom they are contemplating a transaction to determine whether prior secured creditors claim an interest in any or all of that person's assets." 72 Because each filing search is done under the name of the prospective debtor, the searcher's ability to find a relevant financing statement depends on the accuracy of the debtor's name on the statement (and, by extension, on the searcher's understanding of what the debtor's name on any such statement "should" be). If the debtor's name on a financing statement is incorrect, or if the searcher otherwise searches under a version of the debtor's name other than that which is listed on the statement, the search will fail to disclose that statement, even though it was filed. Using the correct debtor's name is thus essentialto Article 9's filing system. ${ }^{73}$

Accordingly, Article 9 imposes a strict standard for accuracy in the listing of a debtor's name on a financing statement. Section 9-503 prescribes rules for stating the names of various types of debtors (e.g., registered organizations, decedent's estates, trusts, unregistered organizations, and individuals). ${ }^{74}$ A financing statement must list the debtor's name in accordance with the applicable rule under $\S 9-503$ in order to be sufficient-i.e., in order to be effective to perfect the related security interest. Generally, any finan cing statement that does not list the debtor's name in accordance with the appropriate rule under $\S$ 9-503(a) is deemed to be "seriously misleading" (and, therefore, ineffective) under $\S 9-506(\mathrm{~b}) .{ }^{75}$ Article 9 allows a secured party very little latitude in complying exactly with $\S 9-503$ 's sufficiency-of-debtor's-name rules. The only small margin of error permitted is as set forth in $\S 9$ 506(c). Under that section, even if a financing statement fails "sufficiently" to provide the debtor's name in accordance with $\S 9-503(\mathrm{a})$, the form of the name that is provided will not cause the financing statement to be seriously misleading (and, thus, will not render the statement ineffective) "[i]f a search of the records of the filing office under the debtor's correct name, using the filing office's standard search logic, ${ }^{76}$ if any, would disclose [the] financing statement." 77

\footnotetext{
${ }^{68}$ Livingston, supra note 53, at 116-17; Frisch, supra note 8, at 1015; White \& Summers, supra note 45, at 185. The UCC's adoption of this "notice filing" concept is expressly set forth in Official Comment 2 to $§ 9-502$. That comment explains as follows:

What is required to be filed is not...the security agreement itself, but only a simple record providing a limited amount of information. The notice itself indicates merely that a person may have a security interest in the collateral indicated. Further inquiry from the part ies concerned will be necessary to disclose the complete state of affairs.

UCC § 9-502 cmt. 2 (2010). See Livingston, supra note 53, at $117 \&$ n. 25 (discussing comment 2 to $§ 9-503$ and Part 5's embodiment of "notice filing"); Frisch, supra note 8 , at 1015 \& n.32 (same).

${ }^{69}$ See UCC $\$ 9-502 \mathrm{cmt} .2(2010)$.

${ }^{70}$ UCC $\S \S 9-502(a)(1),(2)$, (3) (2010). A fixture filing or a financing statement covering as-extracted collateral or timber to be cut, requires certain additional information. UCC § 9-502(b) (2010).

${ }^{71}$ UCC $\$ 9-519$ (c) (2010), cited in Livingston, supra note 53, at 117 n. 30

${ }^{72}$ Livingston, supra note 53, at 117-18.

73 See id. at 117 ("The linchpin of the Article 9 filing system has been and remains the debtor's name."); Frisch, supra note 8, at 1015 ("using the correct name is the key to the filing system").

${ }_{74}$ Compare UCC $\$ 9-503$ (1998) (amended 2010) with UCC $\$ 9-503$ (2010) (as amended by 2010 Amendments).

75 See UCC § 9-506(b) (1998) (amended 2010). The only change to §9-506 as a result of the 2010 Amendments is a revision to Official Comment 2 thereto. See UCC § 9-506, cmt. 2 (2010) (as amended by 2010 Amendments).

${ }^{76}$ Nearly all filing searches today are conducted by computer (rather than by hand) through the applicable filing office, sometimes simply by entering the debtor's name on the applicable Secretary of State's official website. Livingston, supra note 53, at 155. Thus, the results of a filing search often depend in significant part on the parameters of the search methodology or "search logic" employed by the filing office's computer database. Id. at 144, 155; see also White \& Summers, supra note 45, at 206-08 (discussing the effect on searches, particularly under individual debtor names, of a filing office's search logic). The search logic employed by some filing offices' databases is more flexible than others. The broader the search logic, the greater the number of " hits" that a particular search term will generate. A more flexible search logic is thus perhaps a bit more forgiving of (at least minor) discrepancies between the debtor's name as listed on the financing statement and the debtor's name as entered in the search. "Depending on the parameters, and particularly the flexibility of the database's search logic, a search request might reveal financing statements that contained certain types of errors in the debtor's name but
} 
While $\S 9-506(\mathrm{c})$ provides some protection in the case of an inadvertent error that is not serious enough to derail a filing search, a secured party must nevertheless endeavor to comply precisely with $\S 9-503$ (a) when listing the debtor's name on a financing statement. At the same time, anyone who searches for financing statements filed against a particular debtor needs to know how that debtor's name is supposed to be listed under $\S 9-503$ (a), in order to know the exact name under which to conduct the search. Thus, for both a filer and a searcher, the starting point is to determine what the applicable rule under $\S 9-503$ (a) is for the type of debtor in question. This is the crux of the problem that existed under the Old Rule.

\section{UNCERTAINTY UNDER THE “OLD RULE” AND ITS REFLECTION IN THE CASE LAW}

Prior to the 2010 Amendments, the Old Rule under $\S 9-503(\mathrm{a})(4)(\mathrm{A})$ merely stated — in somewhat circular fashionthat, if the debtor in question is an individual (i.e., a natural person), "[a] financing statement sufficiently provides the name of the debtor . . . only if it provides the individual . . name of the debtor."78 Under the Old Rule, there was no elaboration anywhere in $\S 9-503$ (a) (or els ewhere in Article 9) as to exactly what constitutes the "individual name of the debtor" for purposes of a sufficient UCC filing.

Effectively a tautology, the Old Rule did not provide particularly helpful guidance. In fact, it provided no guidance at all. This lack of direction resulted in significant uncertainty among both filers and searchers of financing statements as to how an individual debtor's name had to be listed under $\S 9-503 .{ }^{79}$

On first thought, it may seem intuitively simple to determine an individual's correct name for filing (or any other) purposes. However, there are a great many people for whom that turns out not to be the case. This is due in part to the fact that, often, a person has more than one exact "formal" or "legal" name. For example, a person's driver's license, social security card, and birth certificate may each list his or her name a bit differently. ${ }^{80}$ Moreover, a number of people identify themselves by nicknames or informal abbreviations of their "full" names in their business affairs and everyday lives. ${ }^{81}$ Finally, naming conventions in some non-Anglo cultures may cause confusion in certain cases, among those who are less familiar with those conventions, as to whether a particular part of a person's name is his or her surname or first personal name, or whether it is a "middle" name or matronymic. ${ }^{82}$

Not knowing precisely how to list an individual debtor's name on a financing statement increases a secured party's risk of filing a statement that is ineffective to perfect the secured party's security interest in the related collateral. Similarly, uncertainty in postulating how a prior creditor may have listed an individual debtor's name in a previous financing statement increases the risk to subsequent secured creditors of (or certain prospective purchasers from)

might not reveal financing statements with other types of errors." Livingston, supra note 53, at 155 . Many States have adopted the model standard search logic set forth in the Model Rules of the International Association of Commercial Administrators ("IACA"). White \& Summers, supra note 45, at 206-08 \& n.14 (setting forth the text of the IACA model rules and describing the search methodology thereunder); Livingston, supra note 53 , at 155 (describing examples of search results under IACA model search logic). The IACA model search logic will find some variations of (and, thus, some errors in) the name entered as the search term, but obviously will not find all errors - and certainly not most significant ones. For purposes of $\S 9-506$ (c), what matters is whether the search logic of the applicable State would disclose the financing statement in question if the debtor's "correct" name were entered as the search term. See UCC § 9-506(c) (2010); see also Livingston, supra note 53, at 124-25 (discussing “single search” standard under $\S 9-506(c)$ ).

${ }^{77}$ UCC $\$ 9-506(\mathrm{c})(2010)$.

${ }^{78}$ UCC $\$ 9-503(a)(4)(A)$ (1998) (amended 2010).

${ }^{79}$ For further discussions of the uncertainty surrounding how to list an individual debtor's name on a financing statement prior to the 2010 Amendments to UCC § 9-503, see, e.g., Frisch, supra note 8, at 1012-18; White \& Summers, supra note 45, at 205-09.

${ }^{80}$ Smith, supra note 8, at 350-51; Frisch, supra note 8, at 1017; Livingston, supra note 53, at 149.

${ }^{81}$ See, e.g., Peoples Bank v. Bryan Bros. Cattle Co., 504 F.3d 549, 558-59 (5 ${ }^{\text {th }}$ Cir. 2007) (financing statement listed individual debtor's nickname, where debtor frequently used nickname in his business affairs); Clark v. Deere \& Co. (In re Kinderknecht), 300 B.R. 47, 48, 51 (Bankr. D. Kan. 2003), rev'd, 308 B.R. 71 (B.A.P. 10 ${ }^{\text {th }}$ Cir. 2004) (same; debtor even signed his nickname to his bankruptcy petition); Genoa Nat'l Bank v. Southwest Implement, Inc. (In re Borden), 353 B.R. 886, 887-88 (Bankr. D. Neb. 2006) (financing statement listed debtor's nickname, "Mike," under which he often signed legal documents, rather than his full name, "Michael").

${ }^{82}$ See e.g., Corona Fruits \& Veggies, Inc. v. Frozsun Foods, Inc., 48 Cal. Rptr.3d 868 (Cal. Ct. App. 2006) (uncertainty as to how to 1 ist surname of debtor named "Armando Munoz Juarez"); All Business Corp. v. Choi, 634 S.E.2d 400 (Ga. Ct. App. 2006) (uncertainty as to how to list surname of debtor nam ed "Sang Woo Gu"); see also Harry C. Sigman, Improvements (?) to the UCC Article 9 Filing System, 46 GonZ. L. REV. 457, $475-76$ \& n.56 (2011) (discussing challenges of determining surnames in certain cases of debtors with non-Anglo names). 
that debtor. If a later prospective creditor (or non-ordinary-course buyer) ${ }^{83}$ searches for filings under the wrong version of the debtor's name, the searcher may fail to discover the notice of a prior lien on property in which the searcher then proceeds to acquire a security interest (or ownership interest). In both cases, the res ult can be that a creditor ends up with a far-less-than-bargained-for interest in the property that is pledged as collateral for a secured loan. (In the case of a searcher who fails to discover a relevant financing statement, the result might also be that a non-ordinary-course buyer unknowingly takes ownership of property subject to a prior creditor's security interest. ${ }^{84}$ )

As noted in the PA Task Force Report, "[t]he uncertainty under [the Old Rule] as to how to list an individual debtor's name on a financing statement created significant risks for creditors that make secured loans to individuals - particularly creditors that make secured commercial loans to small businesses [operating] as sole proprietorships." ${ }^{85}$ Those risks were brought to light in a series of court cases decided during the decade prior to 2010. In each of those decisions, "the way an individual debtor's name was listed on a financing statement ultimately deprived a secured creditor of the benefit of the security interest it thought it had in the debtor's collateral for a loan." 86

Perhaps the best known of those cases involved a financing statement that a secured lender filed against an individual borrower with the legal name "Terrance J. Kinderknecht." There was confusion as to Mr. Kinderkn echt's "correct" name because he usually identified himself by the nickname "Terry." 87 Even when he eventually filed for bankruptcy, for example, Mr. Kinderknecht signed his bankruptcy petition as "Terry Kinderknecht" (rather than as "Terrance"). 88 Apparently because the borrower typically used that less formal version of his name, the lender listed the debtor as "Terry J. Kinderknecht" on the financing statement in question. ${ }^{89}$ The trustee in the debtor's bankruptcy proceeding sought to avoid the lender's security interest on the ground the interest was unperfected because the financing statement did not list the debtor's correct name. ${ }^{90}$ The trustee argued that (under the Old Rule) the "name of the debtor" required under $\S$ 9-503(a)(4)(A) was the individual debtor's formal, legal name, "Terrance J. Kinderknecht." 91 Because a search under that name using the relevant filing office's standard search logic failed to disclose the financing statement filed against "Terry J. Kinderknecht," the trustee maintained that the financing statement was seriously misleading under $\S 9-506(\mathrm{c}) .^{92}$ In contrast, the secured lender argued that (under the Old Rule) the "name of the debtor" requirement under $\S 9$-503(a)(4)(A) could be satisfied by listing an individual debtor's commonly used nickname. ${ }^{93}$ Noting that (under the Old Rule) Part 5 of Article 9 "offer[ed] no guidance as to what constitutes "the name of an individual debtor," 94 the bankruptcy court found that the UCC did not "limit financing statements of individuals to any particular name, such as a legal name," 95 and held for the lender.

\footnotetext{
${ }^{83}$ See supra note 53 (discussing the rules pursuant to which buyers of goods outside the ordinary course of business take such property subject to any perfected security interest therein).

${ }^{84}$ See id.

85 PA Task Force Report, supra note 38, at 107-08. This issue arises much more often in the business-loan context than in the consumer-loan context "because (1) secured consumer loans typically involve purchase money security interests, which are perfected automatically, and (2) security interests in motor vehicles (the most frequent subject of non-real-estate secured consumer loans) are perfected through notations on the titles to the motor vehicles rather than through the filing of financing statements." Id. at $108 \mathrm{n} .18$ (internal citation omitted).

${ }^{86} \mathrm{Id}$. at 108 .

${ }^{87}$ Clark v. Deere \& Co. (In re Kinderknecht), 308 B.R. 71, 72-73 (B.A.P $10^{\text {th }}$ Cir. 2004).

${ }^{88}$ Id. at 72; see also PA Task Force Report, supra note 38, at 108 (discussing same).

${ }^{89}$ In re Kinderknecht, 308 B.R. at 72; see also PA Task Force Report, supra note 38, at 108 (discussing same).

$90 \mathrm{Id}$. at 72.

${ }^{91}$ In re Kinderknecht, 300 B.R. at 49, rev'd, 308 B.R. 71. The debtor's birth certificate, driver's license and Social Security card each listed his name as

"Terrance J. Kinderknecht." Id.

${ }^{92} I d$. at $49-50$.

93 In re Kinderknecht, 308 B.R. at 73. A search under the name "Terry Kinderknecht" using the filing office's standard search logic did uncover the financing statement in question and, thus, the lender argued that the financing statement was not seriously misleading under $\S 9-506$ (c). In re Kinderknecht, 300 B.R. at 51-56, rev'd, 308 B.R. 71.

${ }_{94}$ The bankruptcy court found that, under the Old Rule, Part 5 did not indicate one way or the other whether "the name of a debt or may be a nickname as opposed to a legal name. Nor [did] the sections [of Part 5] indicate when the name of the debtor may be deemed sufficient." In re Kinderknecht, 300 B.R. at 49 , rev'd, 308 B.R. 71.

${ }^{95} \mathrm{Id}$. at $56-57$.
} 
On appeal, however, a bankruptcy appellate panel of the Tenth Circuit found in favor of the trustee and reversed the bankruptcy court's decision. ${ }^{96}$ The appellate panel, too, noted that (under the Old Rule) § 9-503 "[did] not provide any detail as to the name that must be provided for an individual debtor-it simply state[d] that the "name of the debtor' should be used." 97 Yet the appellate panel rejected the bankruptcy court's interpretation that the "name of the debtor" under § 9-503(a)(4)(A) could include an individual's common nickname. Instead, based on its gleaning of the purpose of § 9-503 as well as certain "practical considerations," the panel found that the "name of the debtor" requirement was, as the trustee had argued, a requirement to list the debtor's legal name. ${ }^{98}$ Accordingly, the appellate panel "found that the financing statement in question was insufficient to perfect the lender's security interest in the borrower's collateral, because the statement did not list the borrower's legal name" 99 and because the failure of a search under the borrower's legal name to disclose said statement rendered the statement seriously misleading under $\S 9-506(\mathrm{c}) .{ }^{100}$ On that basis, the appellate panel held that the bankruptcy trustee could avoid the lender's interest in the collateral. ${ }^{101}$

A similar issue arose in a subsequent case, in which another court took an entirely contrary position as to when an individual debtor's name was (under the Old Rule) sufficiently listed on a financing statement. Despite the difference in the court's approach, however, the result was essentially the same as in the Kinderknecht case: A lender was ultimately found not to have had the security interest it thought it had taken in collateral for a loan.

This later case involved a borrower who operated a cattle business and who took out two secured loans from two separate banks. ${ }^{102}$ The borrower's legal name was "Brooks L. Dickerson." ${ }^{103}$ However, "Dickerson held himself out to the community as Louie Dickerson, and he used this name in bank accounts, bills of sale, and with others with whom he did business." ${ }^{104}$ He took out the first loan in 1999, and granted the first bank a security interest in his cattle. To perfect its interest, the first bank filed a financing statement listing the debtor as "Louie Dickerson." 105 The borrower took out the second loan in 2002, and he granted the second bank, too, a security interest in his cattle. ${ }^{106}$ The second bank's financing statement listed the debtor as "Brooks L. Dickerson." 107 (From the facts of the case, one can infer that, at the time it filed to perfect its interest, the second bank was unaware of the first bank's financing statement. ${ }^{108}$ When the cattle were subsequently sold to a third-party, ${ }^{109}$ each of the banks sought to enforce its security interest in those cattle, and a dispute arose as to which bank had the superior interest. ${ }^{110}$

${ }^{96}$ In re Kinderknecht, 308 B.R. at $72,77$.

${ }^{97} I d$. at 75 (citing Kan. Stat. Ann. § 84-9-503(a)(5)(A)).

${ }^{98} I d$. The appellate panel reasoned that $\S 9-503$ was enacted under Revised Article 9 to "clarify the sufficiency of a debtor's name in financing statements. to foreclose fact-intensive tests" and that requiring the listing of an individual debtor's legal name "is a clear cut test that is in accord with that intent." Id. The panel also analogized a prohibition against listing nicknames for individual debtors to the restriction in § 9-503(c) on the listing of trade names in the case of entity debtors. Id. In addition, the panel found that requiring the debtor's legal name was supported by four practical considerations:

First, mandating the debtor's legal name sets a clear test so as [to] simplify the drafting of financing statements. Second, setting a clear test simplifies the parameters of UCC searches. Persons searching UCC filings will know that they need the debtor's legal name to conduct a search, they will not be penalized if they do not know that a debtor has a nickname, and they will not have to guess any number of nicknames that could exist to conduct a search. Third, requiring the debtor's legal name will avoid litigation as to the commonality or appropriateness of a debtor's nickname, and as to whether a reasonable searcher would have or should have known to use the name. Finally, obtaining a debtor's legal name is not difficult or burdensome for the creditor taking a secured interest in a debtor's property. Indeed, knowing the individual's legal name will assure $I d$. at $75-76$ the accuracy of any search that creditor conducts prior to taking its secured interest in property.

${ }^{99}$ PA Task Force Report, supra note 38, at 108 (citing In re Kinderknecht, 308 B.R. at 73, 76-77).

${ }^{100}$ In re Kinderknecht, 308 B.R. at 73, 76-77.

${ }^{101}$ Id. at 77; see also PA Task Force Report, supra note 38, at 108 (discussing same).

102 Peoples Bank v. Bryan Bros. Cattle Co., 504 F.3d 549, 551-52 (5 $5^{\text {th }}$ Cir. 2007). See also PA Task Force Report, supra note 38, at 108 (discussing same).

${ }^{103}$ Bryan Bros. Cattle Co., 504 F.3d 549 at 558.

${ }^{104} \mathrm{Id}$. at 559 .

${ }^{105} I d$. at 551.

${ }^{106} \mathrm{Id}$. at 552

${ }^{107} I d$.

${ }^{108}$ See PA Task Force Report, supra note 38, at 108.

109 The seller of the cattle was "Glenbrook Cattle Company," and there was a question of fact as to whether Glenbrook was a sole proprietorship of the borrower or, instead, a limited liability company or partnership existing separately from the borrower. The buyer argued that Glenbrook was a separate entity, that the borrower himself could not encumber the property of that separate entity, and that the cattle were therefore sold free and clear of any lien in favor of either bank. In contrast, the banks contended that Glenbrook was merely a sole proprietorship of the borrower, and that "Glenbrook's" cattle were in fact property of the borrower, in which the borrower had the right to grant a security interest. The Fiffh Circuit held that the question of fact as to Glenbrook's status precluded summary judgment in favor of either the buyer or a bank. See Bryan Bros. Cattle Co., 504 F.3d 549 at 553-58.

${ }^{110} I d$. at 553 . 
The second bank argued that, even though the first bank had filed its financing statement earlier, the second bank had the senior security interest in the collateral, because the first bank's financing statement was insufficient to perfect the first bank's interest. ${ }^{111}$ At issue was whether the first bank's financing statement was seriously misleading under $\S 9-506(\mathrm{~b}){ }^{112}$ The second bank contended that it was, because it listed the borrower's nickname rather than his proper, legal name. ${ }^{113}$ The first bank, however, argued "that its financing statement was not seriously misleading" because the second bank "had actual knowledge that Dickerson was known as "Louie Dickerson." 114 (The implication was that the second bank thus should have known to search for financing statements against "Louie Dickerson" before taking its own security interest in the cattle.) The Fifth Circuit, which heard the case on appeal, agreed with the first bank. Because the borrower commonly identified himself by his nickname in his business affairs, the Fifth Circuit determined that the second bank "was put on inquiry notice that a security interest in the property of 'Brooks L. Dickerson' could be listed under the name 'Louie Dickerson." 115 Indeed, the second bank's own files identified the borrower by both names. ${ }^{116}$ The Fifth Circuit thus concluded that the second bank could not have been seriously misled by the first bank's financing statement. Accordingly, it held that 'the first bank's financing statement was sufficient to have perfected the first bank's interest in the cattle, even though the statement had listed the borrower's nickname and not his legal name." 117 As a result, the second bank was left without the first-priority security interest it thought it had taken in the cattle. Instead, at most, it had merely "a second-priority interest that was subordinate to the lien of the first bank." 118

In addition to these and other similar "nickname" cases, ${ }^{119}$ the lack of guidance under the Old Rule also led to litigation arising from uncertainty as to how to list certain non-Anglo names on a financing statement. ${ }^{120}$

One such case, for example, involved a farmer of Mexican origin whose full name was Armando Munoz Juarez. ${ }^{121}$ The farmer subleased land to grow a strawberry crop, and the lessor advanced funds to the farmer to meet certain expenses. To secure the farmer's obligation to repay the funds, the lessor took a security interest in the farmer's crop. ${ }^{122}$ In order to perfect that interest, the lessor filed a financing statement in July 2001, listing the debtor's name as "Armando Munoz."123 Later, the farmer contracted with a food processing company to sell processed strawberries, and the food company also advanced certain funds to the farmer. To secure the farmer's obligation to repay those funds, the food company also took a security interest in certain collateral of the farmer (including the strawberry crop). ${ }^{124}$ In order to perfect its interest, the food company also filed a financing statement, in January

111 Id. at 558. As noted above, under $\$ 9-322(\mathrm{a})(1)$, when two creditors have perfected security interests in the same collateral, the creditor whose interest was perfected first has the prior (or superior) interest. However, under $\S 9-322(a)(2)$, if one creditor has a perfected security interest in the collateral and the other creditor has only an unperfected security interest, the perfected interest has priority, even if the unperfected interest had been the first to attach. See supra note 53 (discussing Article 9's priority rules and citing, inter alia, UCC \$ 9-322(a)). See also supra notes 18 \& 65 (discussing consequences of priority rules, including, in particular, application of cash proceeds of collateral sale to satisfy senior secured creditor before satisfying creditor with subordinate interest in same collateral).

112 Bryan Bros. Cattle Co., 504 F.3d at 559 (citing Miss. Code Ann. § 75-9-506(b)). Interestingly, in Bryan Bros. Cattle Co., the Fifth Circuit appears to have focused more on the general sufficiency-of-debtor' s-name provision in $\S 9-506(\mathrm{~b})$ than on the disclosure-using-search-logic standard set forth in $\S 9$ 506(c).

113 Id. at 558

$114 \mathrm{Id}$. at $558-59$.

$115 \mathrm{Id}$. at 559

116 Id.

117 PA Task Force Report, supra note 38, at 108 (citing Bryan Bros. Cattle Co., 504 F.3d at 559).

${ }^{118}$ Id. (citing Bryan Bros. Cattle Co., 504 F.3d at 558). Ultimately, whether either bank had any security interest in the cattle depended on whether the seller of the cattle was a sole proprietorship of the borrower or an entity separate from the borrower-a material question of fact that required further proceedings. See supra note 109.

119 See, e.g., Genoa Nat'1 Bank v. Southwest Implement, Inc. (In re Borden), 353 B.R. 886 (Bankr. D. Neb. 2006) (financing statement listing debtor's name as "Mike Borden" was insufficient where debtor's legal name was Michael Ray Borden); Nazar v. Bucklin Nat'1 Bank (In re Erwin), 50 UCC Rep.2d 933, 2003 WL 21513158 (Bankr. D. Kan. 2003) (financing statement listing debtor as “Mike Erwin” was sufficient, even though debtor's legal name was Michael A. Erwin); see generally Smith, supra note 8, at 350-51 \& nn. 6-10 (discussing several cases addressing effectiveness of financing statements listing individual debtors' nicknames).

${ }^{120}$ See e.g., Corona Fruits \& Veggies, Inc. v. Frozsun Foods, Inc., 48 Cal. Rptr.3d 868 (Cal. Ct. App. 2006); rev. denied (described below); All B u siness Corp. v. Choi, 634 S.E.2d 400 (Ga. Ct. App. 2006) (financing statement listing debtor as "Gu, Sang Woo" was insufficient because debtor's correct name was Sang Woo Gu).

121 Corona Fruits \& Veggies, $48 \mathrm{Cal}$. Rptr.3d at 869.

122 Id.

123 Id.

${ }^{124} \mathrm{Id}$. 
2002, but the food company's financing statement listed the debtor's name as “Armando Juarez." 125 By July 2002 , the farmer became unable to meet his loan obligations to either creditor, and the lessor then "took back the farm land, harvested the strawberry crop and kept the crop proceeds." 126 In the consolidated collection actions that followed, a dispute arose between the lessor and the food company as to which party had the senior interest in those proceeds.

The dispute turned on whether the lessor's financing statement was effective. That, in turn, depended on whether "Armando Munoz" constituted "the name of the debtor" under the Old Rule. The lessor reasoned that, because the farmer was from Mexico, the determination of his correct name was governed by the naming convention used in Latin American countries. ${ }^{127}$ " "In most Latin American countries, the surname is formed by listing first the father's name, then the mother's name. .. [T] [Tis is exactly opposite [of the] Anglo-American tradition." 128 Accordingly, the lessor argued that the debtor's true last name was "Munoz."129

There was substantial evidence, however, that the farmer's legal surname in the United States was "Juarez." The farmer's photo identification and green card identified him as "Armando Munoz Juarez," as did certain American tax documents and court papers as well as various business records. ${ }^{130}$ Rejecting the lessor's argument as to the applicability of Latin American naming conventions, the California Court of Appeal thus found that the correct name of the debtor for purposes of $\S$ 9-503(a) (under the Old Rule) was "Armando Juarez." 131 Because a filing search under the name "Armando Juarez," using the relevant filing office's standard search logic, failed to disclose the lessor's "Armando Munoz" financing statement, the court found the lessor's statement to have been seriously misleading under $\S 9-506(\mathrm{c}){ }^{132}$ By contrast, the food company's “Armando Juarez" financing statement was effective. The appellate court therefore affirmed a lower court ruling that the food company had a perfected security interest in the crop proceeds that was superior to the lessor's unperfected interest. ${ }^{133}$ As a result, the lessor-which thought it had perfected its interest in the crop-was subordinated to the rights of a subsequent creditor.

\section{RESPONSE TO THE UNCERTAINTY: THE DEVELOPMENT OF THE 2010 AMENDMENTS}

The aforementioned cases, and others like them, ${ }^{134}$ drew attention to two significant, corresponding risks to secured creditors arising from the imprecision of the Old Rule. First, because of the vague standard under the Old Rule, a secured creditor exercising reasonable care in preparing a financing statement could nevertheless perceive a debtor's correct name differently from the way a court would subsequently determine that such name should have been listed in the statement. As a result, the creditor could unknowingly fail to perfect its security intere st. Second, given the lack of any guidance under the Old Rule, a creditor exercising reasonable care in searching for previous financing statements against a prospective borrower could nevertheless fail to anticipate all conceivable variations in the way the borrower's name might have been listed on such statements. As a result, even after a diligent search, the creditor could fail to uncover a prior perfected security interest in the collateral in question, and thus could unwittingly take a security interest in such collateral that was subordinate to the interest of a another creditor.

Such cases starkly demonstrated that reasonable people — whether they be creditors or judges — could often reach different and conflicting conclusions as to what exactly sufficed as "an individual debtor's name" for purposes of a

\footnotetext{
125 Id.

126 Id.

127 Id. at $870-71$

${ }^{128}$ Id. at 871 (quoting People v. Perez, 30 Cal. App.4th 900, 903 n.2 (Cal. Ct. App. 1994)).

129 This is consistent, for example, with the way the farmer signed the sublease with the lessor. Although the sublease listed the farmer's name as “Armando Munoz Juarez," the farmer signed it "Armando Munoz." Id. at 869.

${ }^{130}$ Id. at $869-70$.

${ }^{131} \mathrm{Id}$. at 870 .

132 Id.

${ }^{133} I d$. at 871. For more discussion of Article 9's priority rules and their consequences, see supra notes $18,53 \& 65$.

134 For further discussion of cases concerning the sufficiency of the listing of an individual debtor's name on a financing statement prior to the 2010 Amendments, see Smith, supra note 8, at 350-51 nn. 6-10, cited in PA Task Force Report, supra note 38, at 109 n.29.
} 
financing statement under the broad parameters of the Old Rule. ${ }^{135}$ To alleviate the risks to creditors caused by such uncertainty, the secured lending community pressed for increased clarity in the law. ${ }^{136}$

As an initial response, efforts arose in a number of States to enact non-uniform amendments to $\S 9-503$, to provide greater guidance on how to list an individual debtor's name on a financing statement (and, by extension, how to determine the name to use when searching for financing statements filed against a particular individual debtor). ${ }^{137}$ That approach, however, was far from ideal. A proliferation of differing State requirements for financing statements against individual debtors would, of course, undermine the uniformity in such matters that the UCC is intended to achieve. Furthermore, at least some States' proposed non-uniform amendments were rather poorly conceived and had the potential to do more harm than good. ${ }^{138}$

As those efforts gained momentum, the UCC's sponsors recognized both a need to stem the tide of such nonuniform measures and a need to correct the underlying vagueness in the Old Rule itself. ${ }^{139}$ Accordingly, even though Article 9 had been substantially revised only ten years earlier, the ULC and the ALI appointed the above mentioned ${ }^{140}$ Review Committee in 2008 to consider amendments to $§ 9-503$ 's sufficiency standard for individual debtor names. ${ }^{141}$ At the same time, the Review Committee also considered several other changes to Part 5's filing provisions, as well as a few non-filing-related updates to Article $9 ;{ }^{142}$ but the necessity to refine the individualdebtor-name rule was both the primary impetus for, and the principal focus of, the amendment process. ${ }^{143}$

When it began to consider how best to enhance $\S 9-503$ 's individual-debtor-name requirements, the Review Committee was aware that most of the non-uniform amendments had relied on debtors' driver's license names. For example, amendments to $\S 9-503$ enacted in Texas and Virginia, respectively, each provided that the listing of an individual debtor's name on a financing statement was automatically sufficient if the debtor's name was listed as shown on his or her driver's license. ${ }^{144}$ Using driver's licenses as a guide for how to list an individual debtor's name has obvious merit, as Edwin E. Smith, the chair of the Review Committee, has explained:

The rationale for choosing the driver's license name as the name of the debtor to be provided in order for the debtor's name to be sufficient is that in most cases an individual debtor holds a driver's license that is offered as a form of identification when the debtor seeks to obtain secured financing. For lenders that extend credit on a volume basis, procedures can easily be established for the lender to search the records of the filing office under the driver's license name and to file in the filing office a financing statement providing that name as the name of the debtor. ${ }^{145}$

\footnotetext{
135 See PA Task Force Report, supra note 38, at 109.

136 Smith, supra note 8, at 347 (discussing "strong desire of parties to secured transactions for greater guidance as to what name should be provided for an individual debtor on a financing statement for the financing statement to be sufficient").

137 See id. at 347 \& n.2 (discussing non-uniform amendments adopted by Tennessee, Texas and Nebraska); Frisch, supra note 8 , at 1018 \& n. 49 (discussing non-uniform amendments adopted by Tennessee, Texas and Virginia); Sigman, supra note 82, at 467-68 \& nn.32-33 discussing non-uniform amendments adopted by Tennessee, Virginia and Nebraska).

${ }_{138}$ See Sigman, supra note 82 , at 467-68 \& n.33 (describing a non-uniform amendment in Nebraska, which, though ultimately repealed, would have created a safe harbor under 9-506 for financing statements that would have been disclosed by a search of the debtor's surname, and noting the difficulties in searching for a prospective debtor simply named "Smith"); $i d$. at 467-68 \& n.32 (describing perceived deficiencies in Tennessee and Virginia non-uniform amendments).

139 Smith, supra note 8, at 347 ("It began to appear likely that non-uniform amendments would continue to spread absent a uniform solution to the issue" [of secured parties' desire for greater guidance as to standards for sufficiency of individual debtors' names].); Sigman, supra note 82, at 467-68 (“It was the prospect that nonuniform and perhaps downright foolish provisions would spread around the country that forced the UCC's spons ors to deal with the issue and institute [the] amendment process.") (internal citations omitted).

${ }_{140}$ See supra text accompanying note 31.

141 Smith, supra note 8, at 348-50 (discussing appointment of Review Committee and describing process of drafting, review and approval of 2010 Amendments); Frisch, supra note 8, at 1010-11 (providing brief synopsis of same).

${ }^{142}$ For a description of all changes to Article 9 under the 2010 Amendments, see Smith, supra note 8, at 350-68; For discussions of some of the most significant changes under the 2010 Amendments other than those that deal with the individual-debtor-name issue, see Frisch, supra note 8, at 1019-34; Sigman, supra note 82 , at 481-93.

${ }^{143}$ See generally Smith, supra note 8, at 347-48 (describing reasons for 2010 amendment process); see also Sigman, supra note 82 , at 469 (“"the vast bulk of the time and energy of the Review Committee was devoted to shaping the potential solution for the individual debtor name 'problem"').

144 See Smith, supra note 8, at 347 \& n.2 (providing a description, by the chair of the Review Committee, of Tennessee and Texas non-uniform amendments, which each created a "safe harbor" for an individual debtor's name on a financing statement if that name matched the name on the debtor's driver's license or non-driver identification card).

${ }^{145} \mathrm{Id}$. at 353.
} 
Accordingly, when the Review Committee began its work, it, too, focused on fashioning a sufficiency standard based on individual debtors' driver's license names. ${ }^{146}$

However, there was a significant division of opinion among committee members as to precis ely what role driver's licenses should play under the new rules. ${ }^{147}$ While views initially ranged from those who wanted to make no changes to the Old Rule to those who wanted to accord super-priority status to financing statements listing a debtor's driver's license name, ${ }^{148}$ two primary approaches eventually emerged. One was a "safe harbor" approach, like that taken in the non-uniform Texas and Virginia statutes, pursuant to which a driver's license name would automatically be deemed to be sufficient, but under which a filer could nevertheless choose to list another variation of the debtor's "correct" name, instead. ${ }^{149}$ The other was an "only if" rule that would require all filers to list an individual debtor's name exactly as set forth on his or her driver's license, and would deem any other variation of an individual debtor's name to be insufficient. ${ }^{150}$ Supporters of the "safe harbor" approach apparently felt that a strict "only if" rule would not provide enough flexibility for financing statement filers. ${ }^{151}$ In contrast, those who backed the "only if" rule apparently thought that the looser "safe harbor" alternative would not provide enough certainty for financing statement searchers. ${ }^{152}$

In an attempt to balance its members' competing policy concerns, the Review Committee ultimately drafted two alternative amendments to the individual-debtor-name provision of $\S 9-503$ (a). ${ }^{153}$ The ULC and the ALI approved both alternatives, and left it to each State to decide which of the two versions to adopt. ${ }^{154}$

Under the first alternative, in the case of a debtor who "is an individual to whom [the] State ${ }^{155}$ has issued a [driver's license] $]^{156}$ that has not expired,"157 a financing statement sufficiently provides the name of the debtor "only if the

\footnotetext{
${ }^{146}$ See generally id. at 353-55 (discussing Review Committee's considerations regarding use of individual debtors' driver's license names on financing statements).

${ }^{147}$ See Amelia H. Boss \& Kenneth C. Kettering, Dissenting Statement Pertaining to the Name of an Individual Debtor on a Financing Statement -Appendix to Report on the Amendments to Article 9 of the Uniform Commercial Code, 84 PA BAR ASs'N QUARTERLY, 176, 178 (2013) [hereinafter, the PA Task Force Dissent] (noting that "[t]he [UCC's] national drafting committee could not . . . agree on one feature of this new rule]" —viz., the role of driver's license names in determining the sufficiency of individual debtors' names on financing statements).

148 Sigman, supra note 82 , at 469.

149 See Smith, supra note 8, at 352-53 (discussing “safe harbor" approach under UCC § 9-503(a)(4) (Alt. B)).

${ }^{150}$ See id. at 351-52 (discussing "only if" approach under UCC § 9-503(a)(4) (Alt. A)).

151 See, e.g., id. at 353-54 (discussing insufficiency of financing statement under “only if' rule if individual debtor's driver's license expires or if debtor changes his or her driver's license name).

${ }^{152}$ See, e.g., id. at 354, 355 (noting that lending community thought that greater certainty of driver's license rule outweighed risk of name-changes, and noting American Bankers Association's preference for “only if" rule).

${ }^{153}$ Frisch, supra note 8 , at 1018 .

${ }^{154}$ Id.; Smith, supra note 8, at 351; see also PA Task Force Dissent, supra note 147, at 178 (noting that, because of lack of agreement among Review Committee members, "the official text of the 2010 [A]mendments sets forth two alternative versions of the rule [for individual debtors' names] for enacting [S] tates to choose between").

${ }^{155}$ Whenever mentioning driver's licenses, $\S$ 9-503(a)(4) and 9-503(g) of the UCC refer to a license issued by "this State," meaning the jurisdiction that has adopted the version of the UCC in question. See UCC $\$ \S 9-503(\mathrm{a})(4)$ (Alts. A and B), 9-503(g) (2010) (as amended by 2010 Amendments). As noted by Edwin E. Smith, chair of the Review Committee, a “driver's license name is relevant for a particular [S]tate only if Article 9's choice of law rules in the forum [S]tate point to the law of that particular [S]tate to determine perfection and the effect of perfection and non-perfection of a security interest that must or may be perfected by filing." Smith, supra note 8, at 354 (citing UCC $\$ 9-301$ ). Thus, for example, if an individual debtor's principal residence is in Illinois, a financing statement against that debtor must be filed in Illinois, and only a driver's license issued to the debtor by the State of Illinois (as opposed to any other jurisdiction) would be relevant for determining the debtor's correct name for listing on the financing statement. See id.

${ }^{156}$ Under either Alternative A or Alternative B, if a State issues both driver's licenses and non-driver identification cards, then the term "driver's license" in $\S 9-503(a)(4)$ should be replaced with the phrase "driver's license or identification card," and either form of identification should be given equal effect. A Legislative Note to both Alternative A and Alternative B provides that, when a State issues non-driver identification cards, such cards should be treated as synonymous with driver's licenses issued by that State, for purposes of the State's version of § 9-503(a)(4). See UCC § 9-503, Legislative Note 3 (2010) (as amended by 2010 Amendments). If an individual debtor in an Alternative A State does not have an unexpired driver' s license (or, depending on the State, an unexpired non-driver identification card), the debtor's name is sufficient under Alternative A if the financing statement "provides the individual name of the debtor or the surname and first personal name of the debtor." See UCC § 9-503(a)(5) (Alt. A) (2010) (as amended by 2010 Amendments). No similar special rule for debtors without driver's licenses is necessary in Alternative B jurisdictions, given the first two sub-rules within Alternative B (as discussed below). See UCC $\$$ 9-503(a)(4)(A)-(B) (Alt. B) (2010) (as amended by 2010 Amendments).

${ }^{157}$ If the State has issued more than one unexpired driver's license to an individual debtor, the most recent license controls. See UCC § 9-503(g) (Alt. A) (2010) (as amended by 2010 Amendments).
} 
statement provides the name of the individual which is indicated on the driver's license."158 This is "Alternative A" under $\S 9-503(\mathrm{a})(4)$, as amended by the 2010 Amendments. ${ }^{159}$ Alternative A embodies the "only if" rule.

Under the second alternative, "if the debtor is an individual," a financing statement sufficiently provides the name of the debtor only if the statement: "(A) provides the individual name of the debtor; (B) provides the surname and first personal name of the debtor; or (C) . . provides the name of the individual which is indicated on [an unexpired driver's license] that [the] State has issued to the individual."160 This is "Alternative B" under $\S 9-503(a)(4)$, as amended by the 2010 Amendments. Alternative B embodies the "safe harbor" approach.

\section{ALTERNATIVE A PROTECTS FILERS AND SEARCHERS OF FINANCING STATEMENTS BY MANDATING UNIVERSAL COMPLIANCE WITH A UNIFORM CONVENTION FOR LISTING INDIVIDUAL DEBTOR NAMES IN FINANCING STATEMENTS}

The raisons d'être of Alternative A and Alternative B are to eliminate the uncertainty that had existed under the Old Rule and to alleviate the risks to both filers and searchers of financing statements that had stemmed from that uncertainty. For the reasons explained below, Alternative A accomplishes those goals far better than Alternative B.

During the debate surrounding the adoption of the 2010 Amendments, one member of the Review Committee, Harry Sigman, maintained that the Old Rule did "not present unmanageable difficulties, as a searcher could [have] easily search[ed] under several name variations and the filer could [have] easily file[ed] against several name variations."161 Indeed, many filers proceeded in just that manner: To try to protect against the risk of listing an individual debtor's name incorrectly, "some creditors filed multiple financing statements against the same debtor, using the debtor's legal name, nicknames, and myriad variations of each."162

One effect of such "over-filing," however, is that it increases the number of variations of a debtor's name that a subsequent prospective creditor has to anticipate when conducting a search for previous financing statements against that debtor. The greater the number of filings, the greater the chance that a reasonably prudent searcher might mis $\mathrm{s}$ one. This is particularly true, for example, when multiple filings against a single debtor include different nicknames of the debtor or alternative presentations of the debtor's non-Anglo name. In some such cases, even the most diligent searcher might not be able to guess every obscure or improbable name-variation that a prior filer listed, and the searcher may fail to discover an effective ${ }^{163}$ financing statement against the debtor as a result. Thus, the practice of over-filing, which Mr. Sigman mentions approvingly as a protection for filers, significantly "exacerbate[ed] the risk to searchers."164

In response to the fact that, under the Old Rule, filers sometimes found it difficult to readily discern the correct form of a debtor's name to list on a financing statement, Mr. Sigman rhetorically questioned whether it was "the law or the poor practice of some secured parties that needs changing." ${ }^{65}$ In particular, he wondered why the creditor in the "Terry Kinderknecht" case filed against the name "Terry" when "the debtor's birth certificate, driver's license and social security card all presented his name as "Terrence."'166 The answer, of course, is simple. From the facts of the

\footnotetext{
${ }^{158}$ UCC § 9-503(a)(4) (Alt. A) (2010) (as amended by 2010 Amendments).

${ }^{159}$ Under Alternative A, if the State has not issued an unexpired driver's license to an individual debtor, then a financing stat ement sufficiently provides the debtor's name if it "provides the individual name of the debtor or the surname and first personal name of the debtor." UCC § 9-503(a)(5) (Alt. A) (2010) (as amended by 2010 Amendments).

${ }^{160}$ UCC \$ 9-503(a)(4) (Alt. B) (2010) (as amended by 2010 Amendments). As under Alternative A, if the State has issued more than one unexpired driver's license to an individual debtor, the most recent of those licenses is given effect under clause (C) of Alternative B. See UCC $\S 9-503$ (g) (Alt. B) (2010) (as amended by 2010 Amendments).

161 Sigman, supra note 82 , at 461.

162 PA Task Force Report, supra note 38, at 109. Cases decided under the Old Rule (such as the ones described supra in Part III) had "created a level of uncertainty that [had] led secured parties to search and file financing statements under multiple names." Smith, supra note 8, at 351.

163 Under the vagaries of the Old Rule, the improbability of a particular variation of a debtor's name would not necessarily have precluded a court, exercising its own judgment, from concluding that such variation is sufficient for a financing statement. One need only look to the Fiffh Circuit's "Louie Dickerson" decision to find evidence of this problem. See supra text accompanying notes 102-18 (discussing Bryan Bros. Cattle Co.).

${ }^{164}$ PA Task Force Report, supra note 38, at 109.

165 Sigman, supra note 82 , at 467.

166 Id.
} 
case, one can infer that the debtor routinely identified himself as "Terry" in his business affairs. ${ }^{167}$ Simply put, that is presumably the name by which the creditor knew him. At the same time, nothing in the Old Rule instructed the creditor to conform to a birth certificate, driver's license or social security card when listing the debtor's name in the financing statement. Under those circumstances, it does not seem unreasonable (at least in this author's view) for the creditor to have filed against "Terry J. Kinderknecht."

In the absence of a rule that dictated a particular form of debtor's name, can one really argue that it was wrong for a creditor to file against "Louie Dickerson" when the debtor used that name (rather than his formal legal name) in his business dealings?" 168 Or that it was careless of a creditor in the "Armando Munoz Juarez" case to be guided by Latin American naming conventions when listing the name of a debtor from Mexico? ${ }^{169}$ Even if one concludes in retrospect that these particular creditors might have used better judgment, the fact remains that such judgment calls are not always easy, and filers acting in good faith can become tripped up when the law does not provide adequate guidance.

Under the Old Rule, figuring out the "correct" name of an individual debtor to list on a financing statement could sometimes be confusing for a variety of reasons. In cases where more than one version of a particular debtor's name could have seemed intuitively correct, the problem was that the Old Rule required everyone involved - the creditor who filed the statement, subsequent prospective creditors who later searched for the statement, and courts that ultimately reviewed the statement if and when a dispute arose-to exercise their own judgment in figuring out which version(s) of the name to choose. If those parties reached conflicting conclusions as to whether a particular form of an individual debtor's name was sufficient, a creditor would often end up without the security interest that it thought it had.

The only real solution to that problem was, and is, to take the exercise of discretion out of the process. Instead of making each relevant party engage in conjecture about the "correct" form in which to list (or search for) an individual debtor's name, there needs to be one uniform convention for listing such names that every filer is always required to follow-in every case, without exception. ${ }^{170}$ When filers are required to adhere to such a convention, searchers will always know which name(s) to search under, and courts will easily (and predictably) decide whether a filing is sufficient simply by determining whether the convention was followed. Tying the sufficiency of the debtor's name under $\S 9-503(\mathrm{a})(4)$ to the name on the debtor's driver's license provides a sensible convention to follow, ${ }^{171}$ and both Alternative A and Alternative B adopt a version of the driver's license rule. ${ }^{172}$

The great advantage of Alternative A, however, is that it makes adherence to the driver's license rule uniform by making "conformity to that convention mandatory." 173 In an Alternative A jurisdiction, the filer of a financing statement need not ruminate over how to list the debtor's name. As the PA Task Force Report pointed out, a filer under Alternative A "is neither required to reach its own judgment nor permitted to s ubstitute its own judgment as to which variation of a debtor's name to use. Instead, the filer is compelled simply to copy verbatim whatever name is listed on the debtor's current driver's license (or non-driver identification card)."174

Of course, not all Review Committee members recognized Alternative A as the superior choice. (Hence, the existence of Alternative B.) For example, Review Committee member Harry Sigman has argued that the driver's license rule "may well not produce the certainty imagined by its proponents" and that Alternative A "still requires

\footnotetext{
167 The fact that the debtor signed his bankruptcy petition using the name “Terry" is strong evidence of that fact. See In re Kinderknecht, 308 B.R. at 72.

168 See Bryan Bros. Cattle Co., 504 F.3d at 559.

169 See supra text accompanying notes 121-33 (discussing Corona Fruits \& Veggies).

170 See PA Task Force Report, supra note 38, at 109 (discussing need to replace individual discretion or personal judgment with a uniform convention for determining individual debtors' correct names).

${ }^{171}$ For an explanation (by the chairman of the Review Committee) of why the driver's license rule makes sense, see supra text accompanying note 145 .

172 Compare UCC $\S 9-503(a)(4)$ (Alt. A) (2010) (as amended by 2010 Amendments) and UCC § 9-503(a)(4)(C) (Alt. B) (2010) (as amended by 2010 Amendments).

${ }^{173}$ PA Task Force Report, supra note 38, at 109.

174 Id.
} 
some human analysis" when listing an individual debtor's name on a financing statement. ${ }^{175}$ To make his point, he offers examples of people whose driver's license names include formal professional titles or unused middle names, maiden names, matronymics or patronymics, or contain typographical errors. ${ }^{176}$ In addition, he laments that the "adoption of Alternative A might well result in the exclusive sufficiency of a name that the debtor has never in fact used" and that "any greater certainty resulting from Alternative A might be achieved by shifting away from the debtor's 'actual' name as used in all other contexts."177 Mr. Sigman apparently believes that, when presented with a driver's license name that contains such a quirk or differs in such a way from an individual debtor's "actual" name, a filer operating under Alternative A would still face uncertainty as to how the debtor's name should be listed on a financing statement.

In this author's view, not only are those arguments unpersuasive; they actually demonstrate why Alternative A is needed and why it is preferable to Alternative B. Differences between a debtor's driver's license name and his or her "real" name do not call for any human analysis or present any uncertainty whatsoever, once the filer knows that the only version of an individual debtor's name permitted on a financing statement is the literal reproduction of the name as it appears on the debtor's driver's license. Under Alternative A's "only if" rule, if a debtor's "real" name is somehow different from the name listed on his or her driver's license, that discrepancy is irrelevant: the filer simply must copy the debtor's driver's license name exactly - no matter what. There is no "analysis" or guess work required in that. Moreover, achieving certainty by "shifting away" from a debtor's more commonly used name is, in the most challenging cases, precisely the goal. Under Alternative A, if a debtor's driver's license identified him as "Terrence J. Kinderknecht" or "Brooks L. Dickers on," a creditor would know that that is the only version of the debtor's name that could be listed on a financing statement - regardless of whether the debtor used the name "Terry" or "Louie" in most other contexts. Yet, unless filers are required always to follow the driver's-license-name convention (which they are not, under Alternative B), a filer in a difficult or unclear case may choose to exercise independent judgment as to the debtor's correct name rather than to follow a rule that (at least in the particular case) is counterintuitive. ${ }^{178}$ The court decisions discussed above demonstrate that allowing filers such leeway can lead to pitfalls for both the filer and subsequent searchers. In short, this is precisely why there needs to be one mandatory convention for determining and listing individual debtors' names. ${ }^{179}$

The possibility of confusion over certain non-Anglo naming conventions presents an especially strong example of why Alternative A is the best approach. If a creditor who deals with a debtor named "Armando Munoz Juarez" is confused as to whether the debtor's surname is "Munoz" or "Juarez" because of lack of understanding as to which naming convention applies, then that misunderstanding is likely to persist regardless of how many official documents identify the debtor by his full name. Given the choice in such a case, the preparer of a financing statement might well opt to follow the convention with which he or she is familiar, rather than to copy the name on a driver's license that just doesn't look right. ${ }^{180}$ At the same time, a court applying a different naming convention

\footnotetext{
175 Sigman, supra note 82, at 472, 475. Indeed, Mr. Sigman, a highly regarded expert on UCC Article 9, went so far as to suggest that the confusion that the Old Rule generated among transaction parties and courts as to the sufficiency of an individual debtor's name on a financing statement did not really warrant any legislative response at all. Id. at 466, 467 (arguing that court decisions indicating uncertainty under the Old Rule did not "demonstrate an urgent need to amend the statute" and criticizing "certain interests" who had "generated an unwarranted ... hysteria about individual debtor names").

176 Id. at $472-73,475-76$.

${ }_{177} I d$. at 476 . Mr. Sigman posits that, “for example, the debtor may provide a middle name or initial in response to a request for that item on the driver's license application, even though the debtor is not known by that name and has never used it on any document." Id.

${ }^{178}$ See, e.g., In re Kinderknecht, 300 B.R. at 49, rev'd, 308 B.R. 71 (creditor filed against "Terry J. Kinderknecht", despite fact that debtor's driver's license identified him as "Terrance J. Kinderknecht"); In re Borden, 353 B.R. at 887-88 (creditor filed against "Mike Borden," even though debtor's driver's license identified him as "Michael R. Borden"). Cf. Bryan Bros. Cattle Co., 504 F.3d at 558 (creditor filed against "Louie Dickerson" because that is the name by which debtor commonly identified himself, despite fact that debtor's formal, legal name was "Brooks L. Dickerson"); Corona Fruits \& Veggies, 48 Cal. Rptr.3d at 870 (creditor filed against "Armando Munoz", although debtor's government-issued identification referred to him as "Armando Munoz Juarez").

179 Of course, the price of adopting any rule based on convention is that the convention may occasionally produce a somewhat arbi trary result. It is admittedly odd, for example, to have to list a debtor named "James Smith" as "Janes Snith" if the latter name appears on his driver's license due to a typographical error. But such cases will presumably be rare and, even then, any filer aware that Alternative A applies would know that the debtor's driver's license name still has to be copied verbatim. Alternative A is workable in virtually all fact-patterns because it provides a narrow, bright-line rule that can be interpreted literally and applied mechanically, by rote.

${ }^{180}$ The possibility of a creditor making such a decision is far from remote. In the actual "Armando Munoz Juarez" case, for example, the creditor who followed Latin American naming conventions to list the debtor as "Armando Munoz" was aware that the debtor's green card and other official documents named him as “Armando Munoz Juarez." See Corona Fruits \& Veggies, 48 Cal. Rptr.3d at 869, 871.
} 
might well hold that the financing statement in question is seriously misleading and, therefore, ineffective. ${ }^{181}$ In such cases, Alternative A protects creditors from the perils of misinterpreting the applicable naming conventions because it denies them any choice. If the debtor's driver's license identifies him as "Armando Munoz Juarez," then, under Alternative A, the financing statement must also list him as "Armando Munoz Juarez." End of story. Unlike questions about how to deal with typographical errors or professional titles embedded in driver's license names (which, presumably, are relatively rare), the question of how to deal with unfamiliar naming conventions in financing statements is a real, practical problem that creditors will face with evermore frequency as our society becomes increasingly diverse. If for no other reason, Alternative A is the best approach because it is the most foolproof way to address this is sue. ${ }^{182}$

By telling filers that they always have to copy an individual debtor's name exactly as it appears on the debtor's most recent unexpired driver's license - and that no other version of the person's name will ever work-Alternative A prevents a filer from ever having to "decide" (or guess) how to list an individual debtor on a financing statement. The clarity and narrowness of the direction to filers makes it almost impossible not to follow the rule correctly. For this reason, Alternative A essentially eliminates the risk to secured creditors that existed under the Old Rule, of failing to perfect a security interest due to incorrectly listing an individual debtor's name on a financing statement. Indeed, there is virtually no chance that a court could ever find an individual's debtor's name on a financing statement filed in an Alternative A jurisdiction to be insufficient, as long as the filer had followed the driver's license rule. ${ }^{183}$

Alternative A also greatly reduces the risks to subsequent prospective creditors who search for financing statements filed against an individual before acquiring a security interest in that person's property. It does so by essentially making it useless for any secured creditor ever to file more than one financing statement against the same individual debtor (with respect to the same collateral) using different versions of the debtor's present name. Obviously, filing under multiple versions of an individual debtor's name serves absolutely no purpose when the only financing statement that can be effective is one that lists the name on the debtor's most recent unexpired driver's license (or non-driver identification card). For this reason, in an Alternative A jurisdiction, subsequent creditors of an individual debtor no longer have to worry about searching for financing statements listing unlikely or far-fetched permutations of the debtor's name. ${ }^{184}$ This, in turn, reduces the risk to subsequent creditors that they will acquire a security interest in property without being aware that a prior creditor has a senior interest in that property. ${ }^{185}$

It should be noted that, even under Alternative A, searchers of financing statements filed against a particular individual cannot always limit their searches exclusively to the name on that person's current driver's license. ${ }^{186}$ As the PA Task Force Report pointed out, "[i]n a case where a debtor has significantly changed the name on his or her driver's license (for example, when a married debtor obtains a new license after taking a spouse's surname), the searcher would have to search under both the debtor's present driver's license name and his or her prior driver's

\footnotetext{
181 That, of course, is exactly what happened in the actual “Armando Munoz Juarez" case. See id. at 871.

182 There is one detail with regard to the ordering of first-names and surnames, about which Harry Sigman makes a fair point. In some States, the name on a driver's license is presented in a single line. See Sigman, supra note 82, at 472, 475. In contrast, line 1(b) of Article 9's official form of initial financing statement requires individual debtor's names to be listed by surname first, and then first personal name. See UCC \$ 9-521(a) (2010) (as amended by 2010 Amendments) (setting forth official form of initial UCC financing statement). This might cause a slight increase in thought or effort when reproducing a driver's license name on a financing statement, in some cases. But the solution is hardly to reject the driver's license rule, as Mr. Sigman seems to have suggested. Rather, if uncertainty regarding first-names and surnames raises any questions about how to fit a debtor's driver's license name into the present format of a financing statement, the simple answer would be to amend the financing statement form to replace the four current blocks within Section $1 \mathrm{~b}$ with one open "individual's name" block (similar to the "organization's name" block in Section 1a). Compare with id. (current official form of financing statement).

${ }^{183}$ See PA Task Force Report, supra note 38, at 109 (discussing how “Alternative A protects filers (like the creditor in the 'Terry Kinderknecht' case or the first creditor in the 'Armando Munoz Juarez' case) from listing an individual debtor's name in a way that a court might later find to be insufficient").

${ }_{184}$ See id. (discussing how Alternative A “eliminate[s] any incentive for a creditor to 'over-file' against an individual debtor").

185 As noted above, the same potential risk exists for non-ordinary-course buyers who might purchase property from an individual seller without knowing that a creditor of the seller has a perfected security interest in the property. See supra text accompanying notes 83-84. Alternative A of course equally reduces such risk to such prospective buyers who search for financing statements covering the property in question. For a detailed discussion of the rules governing the effectiveness of Article 9 security interests vis-à-vis different categories of subsequent purchasers of collateral, see supra note 53.

${ }^{186}$ PA Task Force Report, supra note 38, at 110.
} 
license name."187 This is because $§ 9-507(\mathrm{c})$, as revised under the 2010 Amendments, provides that, if a debtor's name on a financing statement was sufficient when filed but later becomes seriously misleading, that financing statement will not be effective to perfect a security interest in any collateral that the creditor acquires more than four months after the name-change, unless the secured party amends the statement within the four-month period to list the debtor's new and correct name. ${ }^{188}$ To ensure perfection of its interest in such after-acquired collateral (if an interest in such collateral has been granted), a prudent creditor will amend a financing statement in such a case, and subsequent searchers of filings against the debtor will have to search under both the new and old names. Of course, prospective creditors who conduct filing searches are already well aware of the need to search under such a debtor's prior name, since the official text of Article 9 prior to the 2010 Amendments had essentially set forth the identical rule. ${ }^{189}$

Thus, Alternative A does not permit (in all cases, at least) a searcher to search only under one version of an individual debtor's name. However, simply having to search under more than one name is not the problem that Alternative A needs, or is intended, to solve. After all, as Harry Sigman has pointed out, running financingstatement searches "under several name variations" is easy and relatively inexpensive. ${ }^{190}$ Yet that approach works only to the extent that the searcher knows which variations to search under. The risk to searchers is the possibility of a stray (but nevertheless effective) financing statement under some odd variation of a debtor's name, which a reasonable searcher would not even think of. This is the risk that Alternative A should, and does, address. True, there are times when a searcher under Alternative A will have to search under a debtor's prior driver's license name-but, in those cases, the searcher will know to do so. The point is that, because Alternative A compels filers against individual debtors always to follow the driver's license rule, searchers in Alternative A jurisdictions do not bear the burden of searching under versions of a person's name that a prudent searcher might not think to consider. ${ }^{191}$

\section{ALTERNATIVE B FAILS TO ELIMINATE UNCERTAINTY IN THE REQUIREMENTS FOR LISTING INDIVIDUAL DEBTOR NAMES BECAUSE IT ALLOWS FILERS TO FOLLOW RULES THAT ARE AS VAGUE AS THE OLD RULE}

In contrast to Alternative A's “only if" rule, Alternative B allows filers to follow any one of three alternative subrules for listing an individual debtor's name on a financing statement. The third prong of Alternative B provides a "safe harbor" for filers who use an individual debtor's driver's license name. In other words, under Alternative B, if

187 Id.

188 See UCC $\$ 9-507$ (c)(2) (2010) (as amended by 2010 Amendments). However, even if the financing statement is not so amended, it will conti nue to be effective to perfect the secured party's interest in collateral that the debtor acquired before, or within four months after, the debtor's name-change caused the statement to become seriously misleading. See UCC $\S 9-507$ (c)(1) (2010) (as amended by 2010 Amendments).

189 The official text of $\S 9-507$ (c)(1) prior to the 2010 Amendments provided that, in the case of a debtor's name-change, a financing statement filed under the debtor's prior name was "effective to perfect a security interest in collateral acquired by the debtor before, or within four months after, the change." UCC $\S 9-507(c)(1)$ (1998) (amended 2010). And the official text of the prior version of $\S 9-507(c)(2)$ provided that "the financing statement [was] not effective to perfect a security interest in collateral acquired by the debtor more than four months after the change, unless an amendment to the financing statement which renders the financing statement not seriously misleading [was] filed within four months after the change." UCC § 9-507(c)(1) (1998) (amended 2010). Although the 2010 Amendments clarify that $\S 9-507$ (c) applies only if the change in the debtor's name has caused a financing statement to have become seriously misleading under $\S 9-506(\mathrm{c})$, the substance and practical effect of $\S 9-507(\mathrm{c})$ remain the same.

190 Sigman, supra note 82 , at 461, 462.

191 See PA Task Force Report, supra note 38, at 110 (concluding that "Alternative A eliminates the possibility of there being any potentially-effective statement listing some other, improbable variation of the debtor's present name (such as the 'Louie Dickerson' financing statement), which a prudent searcher might not reasonably foresee a need to search for") (emphasis in original). Of course, in order for the driver's license rule to work, secured creditors - both filers and searchers - need to be able to ascertain what the name on an individual debtor's driver's license is. A critic might object, for example, that individuals' driver's licenses are not publicly available, as are the registered names of corporations and other registered organizations. Yet that poses a problem only for those who search for filings against random strangers. In practice, most filing searches instead occur because the searcher is contemplating a transaction in which that searcher is to receive a security interest or ownership interest in property from a particular party, and the searcher wants to determine whether that party has granted any prior security interests in the property in question. Plainly, in the course of any such transaction, the searcher will be in contact with the prospective transferor or grantor and will thus be able to obtain a copy of that party's current driver's license (and, when necessary, information concerning his or her prior driver's license) directly from that party. Similarly, to the extent that it is necessary for a creditor to check a debtor's driver's license periodically, to determine whether there has been a name-change that would require amending a financing statement under $\$ 9-507$ (c) (to ensure perfection of the creditor's interest in after-acquired property), requiring the debtor to send a copy of his or her most recent license every so often is qualitatively no different from other periodic notice or reporting requirements that lenders routinely incorporate in loan and security agreements. 
a financing statement lists an individual debtor's name as it appears on his or her most recent unexpired driver's license, the statement is automatically deemed under $\S 9-503$ (a) to list the debtor's name sufficiently. ${ }^{192}$ However, the first two prongs of Alternative B also permit a creditor to file a financing statement that simply lists either (i) "the individual name of the debtor" 193 or (ii) "the surname and first personal name of the debtor" 194 (regardless, in either case, of whether the name so listed matches the name on the debtor's driver's license). Compared to Alternative A, this broader standard under Alternative B provides less protection to either filers or searchers because it makes compliance with the driver's license rule merely voluntary, rather than mandatory.

At first blush, the greater latitude under Alternative B would seem to make life easier, at least for filers. ${ }^{195}$ Yet, on closer inspection, Alternative B actually perpetuates the risk to filers that exists under the Old Rule, because it allows filers to follow the same vague, imprecise criterion that the Old Rule had set forth. Indeed, the first sub-rule under Alternative B - which provides that a financing statement sufficiently lists an individual debtor's name if it lists "the individual name of the debtor" - is virtually identical to the tautological "nonstandard" of the Old Rule. 196 By essentially saying that a financing statement lists the debtor's name if it lists the debtor's name, the first prong of Alternative B misleadingly suggests that virtually any variation of an individual debtor's name will suffice. In so doing, it steers filers away from strict adherence to the driver's license rule, ${ }^{197}$ and thereby significantly weakens the protection that the driver's license "safe harbor" would otherwise provide. Alternative B thus perpetuates the potential for confusion that the 2010 Amendments were intended to eliminate.

Of course, one might question why filers operating under Alternative B would ever choose not to follow the driver's license rule, given Alternative B's “safe harbor" for driver's license names. Indeed, it is likely that, even under the Old Rule, many creditors listed the debtor's driver's license name when filing a financing statement against an individual debtor. ${ }^{198}$ Yet, as the case law makes clear, creditors operating under the Old Rule did not use driver's license names in all instances, ${ }^{199}$ and the same reasons that caused them not to do so under the Old Rule can be expected to cause them not to do so under Alternative B. ${ }^{200}$ The problems under the Old Rule that gave rise to the 2010 Amendments arose when an individual debtor's formal, legal name differed materially from the name that the debtor used in his or her everyday business affairs. In certain of those cases, a creditor determined that the name that the debtor actually used was the correct name to list on the filing - even though the debtor's driver's license or

\footnotetext{
192 UCC § 9-503(a)(4)(C) (Alt. B) (2010) (as amended by 2010 Amendments).

193 UCC $\$ 9-503$ (a)(4)(A) (Alt. B) (2010) (as amended by 2010 Amendments).

${ }^{194}$ UCC $§ 9-503(a)(4)(B)$ (Alt. B) (2010) (as amended by 2010 Amendments).

195 This supposed benefit is entirely chimerical, as explained below. However, to some academic observers, such "latitude" recommended Alternative B over Alternative A. For example, two respected academics on the PA Task Force were so opposed to the task force's recommendation of Alternative A that they prepared a separate dissent in support of Alternative B. See PA Task Force Dissent, supra note 147. They solemnly warned "that creditors in $[\mathrm{S}]$ tates that enact Alternative A will rue the day, once creditors to individuals in those [S]tates begin to lose their security interests to bankruptcy trustees because of filings that would have been perfectly valid under . . . Alternative B." Id. at 182. The crux of the dissenters' argument was that non-attorney employees of filers in Alternative A jurisdictions would rely on their "common-sense understanding of what a person's 'name' is" and thus would not list an individual debtor's driver's license name on a financing statement if, for example, the debtor's name were misspelled on the license or if the debtor had changed his or her name after the license was issued. Id. at 178, 180, 182. In making that argument, the dissenters appear to have assumed that it would be impossible for secured creditors adequately to train their employees always to list an individual debtor's driver's license name on a financing statement, no matter what. That assumption, in turn, would seem to require far too pessimistic a view of those employees' ability to comprehend (and willingness to follow) a clear, straightforward rule. For example, the American Bankers Association-the trade group representing perhaps the lion's share of creditors that employ non-lawyers to prepare financing statements - was presumably confident in bank employees' ability to be trained to adhere to the driver's license rule. Indeed, the American Bankers Association strongly supported Alternative A over Alternative B, precisely because Alternative A is simpler and, thus, more certain. See Smith, supra note 8, at 349 (noting support for Alternative A expressed by working group of American Bankers Association that assisted Review Committee as an observer during deliberations on 2010 Amendments); PA Task Force Dissent, supra note 147, at 178 (same).

196 Compare UCC § 9-503(a)(4)(A) (Alt. B) (2010) (as amended by 2010 Amendments) with UCC § 9-503(a)(4)(A) (1998) (amended 2010).

197 Yes, the pun was intended.

198 During the Review Committee's process of drafting and debating the 2010 Amendments, some proponents of the driver's license rule asserted that the routine practice of secured parties "already was to provide in the financing statement the name shown on the driver's license." Sigman, supra note 82 , at 474 .

199 See, e.g., In re Kinderknecht, 300 B.R. at 49, rev'd, 308 B.R. 71 (creditor filed against “Terry J. Kinderknecht”, despite fact that debtor's driver's license identified him as "Terrance J. Kinderknecht"); In re Borden, 353 B.R. at 887-88 (creditor filed against "Mike Borden," even though debtor's driver's license identified him as "Michael R. Borden").

${ }^{200}$ See PA Task Force Report, supra note 38, at 110 (noting that, " as the above-mentioned 'nickname' cases make clear, not every filer always relie[d] on a driver's license under the [Old Rule], and there is no reason to think that the practices of those filers would necessarily change under Alternative B").
} 
other legal identification listed a different name. ${ }^{201}$ Under Alternative A, creditors in such cases have no choice but to use the name on the debtor's driver's license. But under Alternative B, it is entirely possible that at least some creditors in at least some cases will conclude that the driver's licen se rule is not the best of the three available rules to follow, when the debtor's driver's license name does not match his or her "real" name (just as some creditors sometimes decided when operating under the Old Rule).

Is it not at least possible, for example, that a creditor operating under Alternative B might still file against "Louie Dickerson" rather than "Brooks L. Dickerson," because filing against the latter name seems counterintuitive and Alternative B is satisfied if the financing statement simply lists "the individual name of the debtor"? ${ }^{202}$ In such a case, there would be just as much uncertainty under Alternative B as there was under the Old Rule as to whether the financing statement was effective-and, therefore, just as much risk to both the filer and any subsequent searchers. If the financing statement were ever challenged, the sufficiency of the debtor's name would depend on how the reviewing court interpreted what constitutes "the individual name of the debtor" under the first prong of Altern ative B. Some courts might conclude that the broadly-worded phrase encompasses nicknames, ${ }^{203}$ but others might conclude that it does not. ${ }^{204}$ In the former case, a subsequent creditor who did not think to search under the "Louie Dickerson" nickname could end up having unwittingly taken a security interest in the debtor's property that was subordinate to the filer's senior perfected security interest. In the latter case, the filer's security interest would be unperfected and could thus become subordinate to a subsequent creditor's perfected interest in the debtor's property. Either way, the ambiguity of the individual-name-of-the-debtor requirement, and the conflicting ways in which different parties could plausibly construe that requirement, would create uncertainty that could result in a creditor's failure to get the security interest it thought it had gotten. The results would be just as de pendent on variations in judgment of different secured parties and different courts as under the Old Rule, because Alternative B allows for a standard that is just as vague as the Old Rule.

In contrast, if they were operating under Alternative A, all of Mr. Dickerson's creditors would know that, no matter how counterintuitive it might seem to them, the only name they are permitted to list on a financing statement is the name on Mr. Dickerson's driver's license. By eliminating any exercise of judgment as to which name to list, the narrow direction of Alternative A would thus protect filers from the consequences of any errors in such judgment. At the same time, it would protect subsequent searchers from the consequences of failing to search under peculiar versions of the debtor's name that they might not realize a need to look under. In short, the only way to protect the interests of all filers and all searchers in all cases is to require individual debtors' names always to be listed according to one uniformly recognized convention-the driver's license rule. Viewed in this light, the first two prongs of Alternative B do not provide secured creditors with additional, helpful latitude. ${ }^{205}$ If anything, they set traps for the unwary.

\footnotetext{
201 See, e.g., In re Kinderknecht, 300 B.R. at 49, rev'd, 308 B.R. 71 (creditor filed against "Terry J. Kinderknecht”, despite fact that debtor's driver's license identified him as "Terrance J. Kinderknecht"); In re Borden, 353 B.R. at 887-88 (creditor filed against "Mike Borden," even though debtor's driver's license identified him as "Michael R. Borden"); Bryan Bros. Cattle Co., 504 F.3d at 558 (creditor filed against "Louie Dickerson" because that is the name by which debtor commonly identified himself, despite fact that debtor's formal, legal name was "Brooks L. Dickerson"); Corona Fruits \& Veggies, 48 Cal. Rptr.3d at 870 (creditor filed against "Armando Munoz," although debtor's government-issued identification referred to him as "Armando Munoz Juarez").

${ }^{202}$ A similar hypothetical could be posed with regard to the first creditor in the "Armando Munoz Juarez" case. See supra text accompanying notes 121-33 (discussing Corona Fruits \& Veggies). Is it not plausible that that creditor, if operating under Alternative B, might still have filed against "Armando Munoz," thinking that that name satisfied the second sub-rule of Alterative B, which deems sufficient a financing statement that "provides the surname and first personal name of the debtor"? UCC § 9-503(a)(4)(A) (Alt. B) (2010) (as amended by 2010 Amendments). Harry Sigman argues that the second subrule of Alternative B provides greater certainty for filers than the driver's-license safe harbor. Sigman, supra note 82, at 478 . But, in reality, the surname/first-name sub-rule provides no guidance whatsoever in the case of a debtor with a non-Anglo name, when a creditor acting in good faith (like the first creditor in the "Armando Munoz Juarez" case) is confused as to which portion of the name constitutes the surname and which constitutes the firstname.

${ }^{203}$ That would be the same conclusion that the Fifth Circuit reached under the Old Rule in the actual "Louie Dickerson" case. See Bryan Bros. Cattle Co. , 504 F.3d at 559; see also PA Task Force Report, supra note 38, at 110 (discussing same).

${ }^{204}$ That, in turn, would be the same conclusion as the one that the Third Circuit reached in the "Terry Kinderknecht" case. See In re Kinderknecht, 308 B.R. at 75; see also PA Task Force Report, supra note 38, at 110 (discussing same).

205 It should be noted, in particular, that the first two sub-rules of Alternative B do not provide any additional protection to filers who would otherwise be required (under Alternative A) to follow the driver's license rule. A creditor would not benefit from invoking one of those other sub-rules unless it had filed a financing statement that did not accurately list the debtor's driver's license name. Thus, for those sub-rules to apply, the filer would have to either (1) intentionally choose not to use the debtor's driver's license name or (2) make an extraordinary mistake in copying the debtor's driver's license name.
} 


\section{CONCLUSION: WHAT ARE THE "TAKEAWAYS" FOR TRANSACTION PARTIES AND ENACTING JURISDICTIONS?}

Uncertainty under the Old Rule as to how to list an individual debtor's name on a financing statement caused significant risks to secured creditors (and, in some cases, buyers ${ }^{206}$ ). As the case law demonstrates, even when they acted with reasonable prudence, secured creditors operating under the Old Rule were nonetheless sometimes left without the perfected security interest that they thought they had taken, because they were unsure of the version of an individual debtor's name to file against or the version of such name to search under. The most significant purpose of the 2010 Amendments was to eliminate that uncertainty and protect against those risks.

The best way to ensure that secured parties always know how an individual debtor's name should be listed on a financing statement is to prescribe a uniform convention for listing such names and to make adherence to such convention mandatory. The driver's license rule-i.e., the rule that the debtor's name on the financing statement should match the name on his or her driver's license-is the convention most appropriate to that task. Alternative A requires all financing-statement filers always to follow the driver's license rule. In contrast, Alternative B provides a safe harbor for filers who follow the driver's license rule, but it also permits filers instead to follow other rules for determining how to list an individual debtor's name. Unfortunately, those other rules are every bit as vague and unhelpful as the Old Rule. Accordingly, Alternative A provides the most absolute guidance, and therefore the greatest protection, to both creditors who file financing statements against individual debtors and subsequent prospective creditors (or purchasers) who later search for those financing statements.

As of yet, there are no reported cases concerning the sufficiency of an individual debtor's name on a financing statement that had been filed since the 2010 Amendments became effective. This is hardly surprising, considering that the 2010 Amendments have been effective for only about three years. As secured-transaction parties gain more experience under both Alternative A and Alternative B, any systemic problems that either alternative causes will become reflected in the case law. Thus, as case law under the 2010 Amendments develops, the UCC's sponsors and lawmakers in each enacting jurisdiction should monitor whether (supposedly) secured parties are still "losing" security interests in the property of individual debtors, as a result of how those individuals' names had been listed on financing statements. For the reasons explained above, the potential to suffer such losses appears most likely for secured parties operating in Alternative B jurisdictions. If and when the case law begins to indicate that the abovepostulated risks under Alternative B are actually causing such harms, lawmakers in Alternative B jurisdictions should follow the example of the State of Washington ${ }^{207}$ and switch to Alternative A, and the UCC's sponsors should consider further amending § 9-503(a)(4) to remove Alternative B from the UCC's Official Text.

Until then, filers and searchers in Alternative B jurisdictions ought to proceed with appropriate caution. As we await more information about how Alternatives $\mathrm{A}$ and $\mathrm{B}$ are working in practice, there are two important things that we already know: First, as the prior case law indisputably demonstrates, the Old Rule created significant uncertainty as to when an individual debtor's name was (or was not) sufficiently listed on a financing statement, and such uncertainty resulted in serious risks to filers and searchers of financing statements alike. ${ }^{208}$ Second, Alternative B

\footnotetext{
Under Alternative A, deciding not to use the debtor's driver's license name would be willful disregard of Article 9's filing requirements, and there is no reason to presume that filers would act that way. On the other hand, it is equally hard to imagine that a filer trying in good faith to comply with Alternative A would make a scrivener's error so severe that it would invalidate the financing statement. Under $\S 9-506$ (a), a financing statement that otherwise satisfies Article 9's filing requirements “is effective, even if it has minor errors or omissions, unless the errors or omissions make the financing statement seriously misleading." UCC $\S 9-506$ (a) (2010). In turn, under $§ 9-506$ (c), the listing of a debtor's name is not seriously misleading unless a search under the debtor's correct name would fail to disclose the financing statement. UCC $\$ 9-506$ (c) (2010). Therefore, the filer's copying mistake would have to be so great - and the resulting name on the financing statement would have to be so different from the debtor's actual driver's license name-that searching under the debtor's driver's license name would not enable a searcher to discover the financing statement. As a practical matter, errors of that sort are likely to be extremely rare.

206 As noted above, in some cases, the same risks also extended to certain "non-ordinary-course" buyers of property from persons who had pledged the property as collateral for a secured loan. See supra text accompanying notes 83-84. For more on which purchasers take property subject to a perfected security interest therein (and which do not), see supra note 53.

207 As noted above, the State of Washington originally enacted Alternative B, but prior to the effective date of the 2010 Amendments in that jurisdiction, enacted a subsequent amendment switching to Alternative A. See supra note 41.

${ }^{208}$ See supra Part III (discussing uncertainty and risks under Old Rule).
} 
threatens to perpetuate that uncertainty, because two of the sub-rules within Alternative B essentially reinstitute the Old Rule's vague standard for individual debtor names. ${ }^{209}$ Accordingly, it is imperative that transaction parties be mindful of the problems that had arisen under the Old Rule, whenever filing or searching for a financing statement against an individual debtor in an Alternative B jurisdiction.

Taking the lessons of the Old Rule to heart, every filer of a financing statement against an individual debtor in an Alternative B jurisdiction should always list the debtor's name exactly as it appears on his or her most recent unexpired driver's license $\mathrm{e}^{210}$ (or, where appropriate, on his or her most recent unexpired non-driver identification $\operatorname{card}^{211}$ ), even in a case where another version of the debtor's name might intuitively seem more appropriate. ${ }^{212}$ Under Alternative B's “safe-harbor" for driver's license names, such a listing of an individual debtor's name will always be sufficient. ${ }^{213}$ In contrast, if a filer in an Alternative B jurisdiction chooses to deviate from an individual debtor's driver's license name and, in reliance on one of the other two sub-rules within Alternative B, instead lists a version of the debtor's name that seems to "make more sense," the filer runs the risk that a court subsequently reviewing the financing statement will find the listing of the debtor's name to be insufficient. This is because, like the Old Rule itself, those two prongs of Alternative B provide broad, imprecise standards that are susceptible to differing interpretations. ${ }^{214}$

Unfortunately, a searcher of financing statements filed against an individual debtor in an Alternative B jurisdiction cannot assume that all filers in the jurisdiction will have heeded the foregoing advice. Rather, searchers in an Alternative B jurisdiction must assume that at least some filers against the individual in question did not rely on Alternative B's “safe harbor" for driver's license names and instead filed under another version of the individual's name. Thus, when operating in an Alternative B jurisdiction, a searcher of financing statements against a particular individual must search not only under the name listed on the individual's most recent unexpired driver's license, but also under every other version of the person's name that one might possibly think of. Of course, the risk remains that, no matter how many variations the searcher searches under, a prior creditor will have used yet another version of the individual debtor's name-which the searcher had reasonably failed to consider, but which a court might nevertheless find to be sufficient under one of the first two prongs of Alternative B. ${ }^{215}$

\section{AUTHOR INFORMATION}

Steven Z. Hodaszy, Assistant Professor of Taxation, Robert Morris University School of Business, Moon Township, PA, USA. A.B. (magna cum laude), Amherst College, 1988; J.D., New York University School of Law, 1991; LL.M. (taxation), New York University School of Law, 2010. The author was a member of the Uniform Commercial Code Task Force of the Business Law Section of the Pennsylvania Bar Association, which helped to develop Pennsylvania's version of the 2010 Amendments to UCC Article 9. Prior to teaching, the author was a practicing attorney for approximately 20 years. During much of that time, his practice focused primarily on structured finance and commercial finance. In the course of that practice, the author worked on a substantial number of as set securitizations, secured credit facilities and other transactions involving Article 9 security intere sts.

\footnotetext{
209 See supra Part VI (discussing same).

210 Of course, this requires that the driver's license in question had been issued by the State whose laws govern the perfection, and the effects of perfection or non-perfection, of a security interest pursuant to the Article 9 choice-of-law rules as enacted in the relevant jurisdiction. For example, a financing statement against an individual debtor would have to be filed in the State in which his or her personal residence is located; thus, the debtor's name on a driver's license that had been issued by another State would be irrelevant. For more on the effect of Article 9's choice-of-law rules on the application of the driver's license rule for individual debtor names, see supra note 155.

211 Under both Alternative A and Alternative B, as set forth in the official text of the UCC, a non-driver identification card is to be treated the same as a driver's license in the case of jurisdictions that issue both types of documents. See supra note 156 (discussing UCC § 9-503, Legislative Note 3). However, before relying on the debtor's name as set forth on a non-driver identification card in any particular case, a filer must confirm that the version of the UCC enacted in the relevant jurisdiction gives weight to non-driver identification cards.

212 Such cases might include: (i) cases where an individual debtor commonly uses a nickname in his or her business affairs; (ii) cases where an individual debtor has changed his or her name since his or her most recent unexpired driver's license was issued (e.g., as a result of taking a spouse's surname); or (iii) cases where the debtor's name was misspelled or otherwise incorrectly reproduced on his or her driver's license.

213 See UCC \$ 9-503(a)(4)(C) (Alt. B) (2010) (as amended by 2010 Amendments).

214 See supra text accompanying notes 193-97 (discussing uncertainty inherent in UCC $\$ \S 9-503(a)(4)(A)$ and (B) (Alt. B)).

215 See supra text accompanying notes 200-05 (discussing such risks under Alternative B).
} 


\section{REFERENCES}

Amelia H. Boss \& Kenneth C. Kettering, Dissenting Statement Pertaining to the Name of an Individual Debtor on a Financing Statement-Appendix to Report on the Amendments to Article 9 of the Uniform Commercial Code, 84 PA BAR Ass'N QUARTERLY, 176 (2013)

James Brook, SECuRed Transactions: ExAmPLES ANd EXPlanations (4th ed. 2008)

David Frisch, The Recent Amendments to UCC Article 9: Problems and Solutions, 45 U. Rich. L. REV. 1009 (2011)

Margit Livingston, A Rose by Any Other Name Would Smell As Sweet (or Would It?): Filing and Searching in Article 9's Public Records, 2007 BYU L. REV. 111 (2007)

Report on the Amendments to Article 9 of the Uniform Commercial Code, Secured Transactions-Recommended for Adoption by the Uniform Law Commission on July 16, 2010, 83 PA BAR ASS'N QUARTERLY 101 (2012)

Harry C. Sigman, Improvements (?) to the UCC Article 9 Filing System, 46 GonZ. L. REV. 457 (2011)

Edwin E. Smith, A Summary of the 2010 Amendments to Article 9 of the Uniform Commercial Code, 42 UCC L.J. 345 (2010)

James J. White \& Robert S. Summers, Uniform Commercial Code (6th ed. 2010), Vol. 4 


\section{NOTES}

